\title{
NUTRITIONAL IMPLICATIONS OF GASTROINTESTINAL AND LIVER METABOLISM IN RUMINANTS
}

\author{
C. J. SEAL ${ }^{1}$ AND C. K. REYNOLDS ${ }^{2 *}$
}

${ }^{1}$ Department of Biological and Nutritional Sciences, Faculty of Agriculture and Biological Sciences, University of Newcastle upon Tyne, Newcastle upon Tyne NE1 7RU

${ }^{2}$ Ruminant Nutrition Laboratory, Livestock and Poultry Sciences Institute, USDA Agricultural Research Service, Beltsville MD 20705, USA

\section{CONTENTS}

INTRODUCTION
EXPERIMENTAL TECHNIQUES .
ISOLATED TISSUE PREPARATIONS

\section{INTRODUCTION}

The maintenance of an optimum nutrient balance in ruminant animals for growth, pregnancy and lactation is of key economic importance, requiring a wide range of adaptive responses to supply the necessary metabolites for different physiological states. The splanchnic bed, comprising the gastrointestinal tract and liver, plays a pivotal role in moderating the pattern of nutrients available for peripheral tissues. The intestinal tissues form an interface between the diet and the animal and have a direct influence on the flux of nutrients from the lumen into the bloodstream. The liver then forms the central metabolic junction, further moderating and distributing nutrients to peripheral tissues for maintenance or productive functions such as muscle deposition or milk synthesis. The pattern of nutrients appearing in the bloodstream does not necessarily reflect the quantity and form of those available for absorption from the gut lumen. Gastrointestinal tissues

\footnotetext{
* Present address: Department of Agriculture. University of Reading, Earley Gate, PO Box 236. Reading RG6 2AT.
} 
make use of metabolites produced by extensive metabolism of nutrients within the mucosa during the process of absorption in addition to those available in the arterial supply. This is evident from the significant difference between apparent absorption or disappearance of nutrients from the gut lumen and appearance of metabolites in the bloodstream (Bergman \& Wolff, 1971; Tagari \& Bergman, 1978).

\section{EXPERIMENTAL TECHNIQUES}

Techniques available for the investigation of nutrient absorption and possible interactions with other dietary components include many in vitro and in vivo procedures which have contributed to our understanding of nutrient availability. These procedures are also used to study specific metabolic processes within tissue types and across tissue beds.

\section{ISOLATED TISSUE PREPARATIONS}

The use of everted gut sacs made from intestinal segments was first developed by Wilson \& Wiseman (1954) to investigate sugar transport (Crane \& Wilson, 1958) and has since been applied to many other nutrients including amino acids (Phillips et al. 1976) and trace elements (Pearson et al. 1966; Seal \& Heaton, 1983; Seal \& Mathers, 1989). The relative insensitivity of the technique and the experimental difficulties associated with maintaining normal metabolic activity in the isolated tissue (Munck, 1972) have meant that this procedure has to a large extent been superseded by the use of isolated membrane vesicles developed from the initial methods of Kaback (1960). These methods have provided much of our present knowledge of amino acid uptake and transport, especially in the determination of specific rates of uptake and interactions and competition between different amino acids (Christensen, 1990). More recent approaches, which bridge the gap between artificial cells prepared from isolated membranes and intact cells in vivo, have centred on the use of tissue cultures of intestinal epithelial cell lines grown in monolayers (for review, see Hidalgo et al. 1989). In addition, isolated ruminal epithelial cells and papillae have been used to investigate developmental and diet induced changes in ruminal tissues (Harmon et al. 1991 a; Baldwin \& Jesse, 1992, 1993). Identification and localization of individual transport systems now involve the use of molecular biology techniques and have been applied to whole animal investigations. For example, the sodium-glucose cotransporter has been sequenced and characterized at the molecular level (Hediger et al. $1987 a, b)$ and polyclonal antibodies raised to a synthetic polypeptide corresponding to a section of the sequence have been used to investigate the development and dietary regulation of glucose transport systems in neonatal lambs (Shirazi-Beechey et al. 1991 a, b). Further development of these techniques will undoubtedly expand our knowledge of nutrient transporters.

Much of our understanding of liver nutrient metabolism and biochemistry is founded on in vitro studies using liver slices (Krebs \& Henseleit, 1932) and homogenates (Ratner, 1947). As with intestinal cells, liver cells can be isolated, incubated and maintained as long as four days (Pogson et al. 1984), but prolonged monolayer culture has only recently been used to study metabolism of ruminant hepatocytes; their metabolic viability is often shortlived when maintained in culture (Faulkner \& Pollock, 1990) and much of the in vitro work on ruminant hepatocyte metabolism has been limited to short-term incubations (Aiello et al. 1989). In vitro studies have provided and will continue to provide invaluable insights into specifics of liver biochemistry and metabolism. However, limitations of in vitro procedures must be considered when applying data obtained in vivo. The heterogeneity of 
cells obtained is considerable, both in terms of cell type and location relative to blood supply. In addition, the lack of blood flow for delivery of substrate and removal of waste, as well as the limited metabolite exchange between cells, affects the viability and sensitivity of incubated cells. Supraphysiological concentrations of substrates are often required to maintain cell viability and elicit a metabolic response, and metabolic responses to substrate additions in vitro can differ markedly from responses observed in vivo (Reynolds $e t$ al. $1992 c)$.

\section{WHOLE ANIMAL EXPERIMENTS}

Approaches for the study of liver metabolism in vivo include hepatectomy or portacaval shunts to remove the contributions of liver metabolism (Shoemaker, 1964). In addition, the isolated perfused liver has proved a useful approach for studying metabolism of the intact liver using strict control of substrate delivery. First used in 1875, the technique is effectively a 'bridge between in vitro and in vivo studies' (Shoemaker, 1964). By comparing responses to antegrade and retrograde infusion of substrates, the isolated perfused liver has recently been used to determine the degree to which zonal distribution of hepatocytes along the liver acinus affects the metabolism of specific compounds (Häussinger, 1983).

In vivo techniques such as ligated intestinal loops and intestinal perfusion procedures have been extensively applied with rats to investigate intestinal uptake, but their application in large animals is costly and impractical. Early studies of rumen volatile fatty acid absorption and metabolism did, however, use anaesthetized sheep in this way (Pennington, 1952). Current understanding of the flow of nutrients along the gastrointestinal tract of large animals has been achieved through the extensive use of permanent or semi-permanent intestinal cannulae (Brown et al. 1968), which together with the use of non-absorbable marker substances (Owens \& Hanson, 1992) allow the processes of digestion to be studied in different regions of the intestine. This approach, however, is limited by the nature of the preparations to measuring the rate of disappearance of substances from the digesta, and takes no account of the fate of these nutrients once they leave the gut lumen. The situation is further complicated by recycling of nutrients and secretory products back into the lumen, together with intestinal cells sloughed during villus growth and development.

The use of multicatheterization procedures has made the largest contribution to our knowledge of this area of ruminant gastrointestinal and liver metabolism. Originally developed for use in the study of liver metabolism in dogs (Shoemaker et al. 1959), the technique has been applied to sheep (Katz \& Bergman, 1969a,b) and cattle (Symonds \& Baird, 1973; Huntington et al. 1989) to measure net absorption and metabolism of nutrients across the splanchnic bed. When used in combination with other techniques such as liver biopsy (Shoemaker, 1964), digestion trials and calorimetry (Reynolds et al. 1991 b), measurements of digesta flow and nutrient disappearance from the gut lumen (Tagari \& Bergman, 1978) or infusion of nutrients into the rumen (Huntington et al. 1983; Seal \& Parker, $1991 a, 1993 a, b$ ), abomasum (Guerino et al. 1991) or intravenously (Baird $e t$ al. 1980; Balcells et al. 1992) the technique can yield invaluable data describing the role of the splanchnic bed in the delivery of nutrients to peripheral tissues. The combination of multicatheterization techniques and isotopic measurements of nutrient turnover also enables the measurement of unidirectional metabolism by portal drained viscera (PDV) and liver (Bergman, 1975). 


\section{MEASUREMENT OF BLOOD FLOW}

Application of the Fick principle (Zierler, 1961) to measurements of venous-arterial concentration differences of nutrients and blood flow in the venous drainage is used to calculate net rates of metabolism across tissues. Intravascular infusions of radiolabelled substrates and measurement of changes in metabolite specific activity across tissues are used to differentiate between these net flux rates and actual utilization rates within tissues (Bergman et al. 1970). The key determinant for both these processes is the accurate measurement of blood flow. Several techniques have been used including indicator dilution or liver clearance using sulphobromophthalein (Bradley et al. 1945), labelled erythrocytes (Schambye, 1955; Conrad et al. 1958), indocyanate green (Shoemaker, 1964; Wangsness \& McGilliard, 1972), para-amino hippuric acid (PAH) (Roe et al. 1966), thermal dilution methods (White et al. 1967), and electromagnetic or Doppler electronic flow probes (Carr \& Jacobson, 1968; Prewitt et al. 1975; Durand et al. 1988; Huntington et al. 1990). There have been recent improvements in the use of the Doppler principle for measurement of total volume flow in blood vessels, but anatomical constraints at the junction of the anterior mesenteric, gastrosplenic and gastroduodenal veins limit the usefulness of this technique in most cattle (Huntington et al. 1990). In sheep, which are more likely to have a common portal vein, the probes have been used successfully for measurements of portal vein blood flow (E. N. Bergman, personal communication), although the measurement of hepatic artery or total liver blood flow is also required for measurement of liver flux. Liver clearance techniques must be used in combination with other techniques for measuring portal vein flow in order to calculate liver flux (Shoemaker, 1964), although many researchers assume portal flow contributes a fixed proportion of liver flow and do not obtain direct measurements. To date the majority of studies in ruminants has used PAH dilution as the preferred method for measuring blood flow in long term studies. As PAH is acetylated in the liver, analytical procedures developed for sheep include deacetylation (Katz \& Bergman, 1969b). In cattle, deacetylation affects total concentration of PAH measured using automated procedures, but not venous-arterial concentration differences, and therefore does not affect blood flow determinations (Huntington, 1982).

\section{RUMINANT SPLANCHNIC VASCULATURE}

Anatomical differences between bovine and ovine splanchnic vasculature are highlighted in Fig. 1. The collateral branch of the mesenteric vein (h) in the bovine is not found in the sheep and forms a looped structure in the mesenteric drainage of this species, through which venous blood may flow in either direction before mixing at the anterior mesenteric vein $(\mathrm{g})$. In cattle, the junction of anterior mesenteric and gastrosplenic veins occurs over a relatively shorter distance than that in the sheep, where the separation of these vessels is generally more distinct, with the gastrosplenic vein joining at a less acute angle to the mesenteric vein. This provides a common portal vein prior to the porta hepatis which is often not present in cattle. Consideration of these differences is important in the location of catheters for measuring absorption across the mesenteric drained viscera (MDV) and PDV in these species. Tissues of the PDV include the entire digestive tract and associated organs comprising the pancreas, spleen and mesenteric fat. Catheters inserted into specific blood vessels can therefore be used to identify metabolism across specific tissue beds. The gastrosplenic vein drains the rumen, reticulum, omasum, cranial abomasum, spleen and pancreas; the anterior mesenteric vein the small intestine, caecum, large intestine, mesenteric fat and pancreas; and the gastroduodenal vein the caudal abomasum, cranial duodenum and pancreas. Measurements of venous-arterial concentration differences from 
(a)

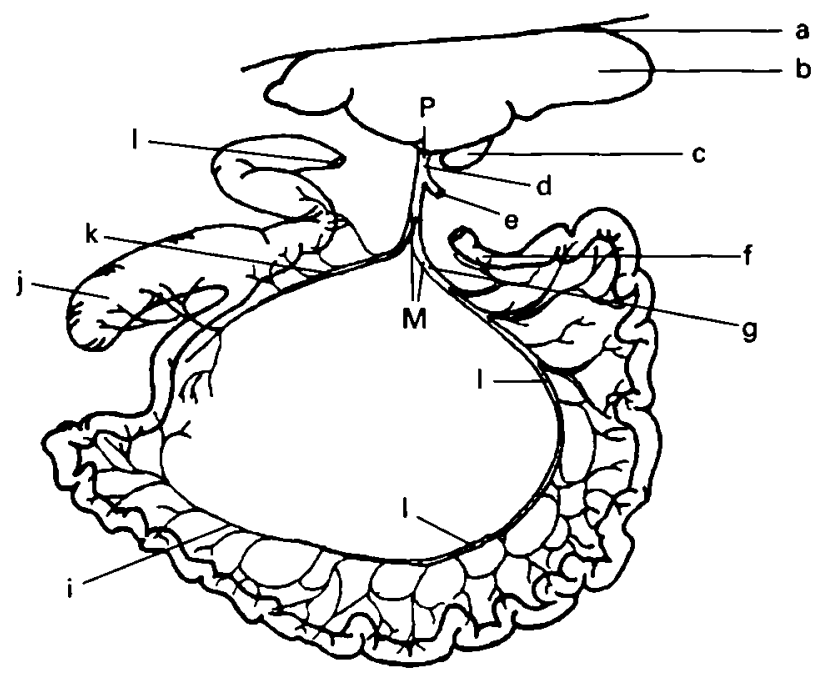

(b)

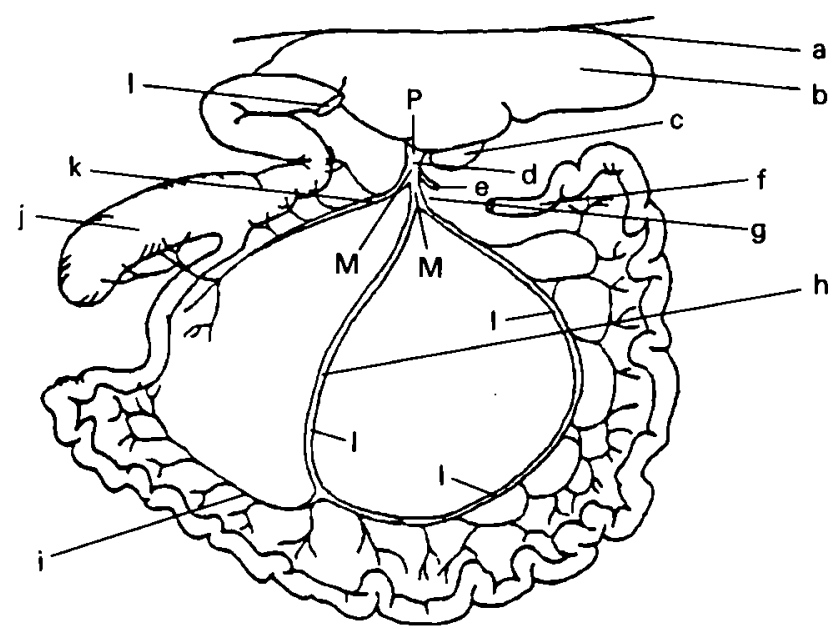

Fig. 1. Schematic view of ovine $(a)$ and bovine $(b)$ splanchnic vasculature showing anatomical differences between the two species (adapted from Huntington et al. 1989). a, Diaphragm; b, liver; c, gall bladder; d. portal vein; e, gastrosplenic vein; $f$, jejunum: g. anterior mesenteric vein; $h$, collateral branch of mesenteric vein ; i, distal branch of mesenteric vein; $j$, caecum; $k$, ileocaecal vein; 1 , large intestine; 1 , sites of infusion catheters; $M$, sites of mesenteric sampling catheters; $P$, site of portal sampling catheter.

these vessels have been used to differentiate stomach and post-stomach absorption of nutrients (Reynolds \& Huntington, $1988 a, b$; Seal et al. 1992).

Generally there are three to five major and any number of smaller hepatic veins which empty into the bovine vena cava (Fig. 2). These major veins drain the left lateral lobe (one or two veins), central liver (one or two veins draining the quadrate and right lobes) and the caudate process. Using a paracostal or 12 th rib resection for surgical approach, the central vein, usually lying adjacent to the gall bladder, is the most accessible and drains the largest portion of the liver (Huntington et al. 1989). However, most workers with sheep have used a branch of the left lateral vein for catheterization (Katz \& Bergman, 1969a). Assuming 


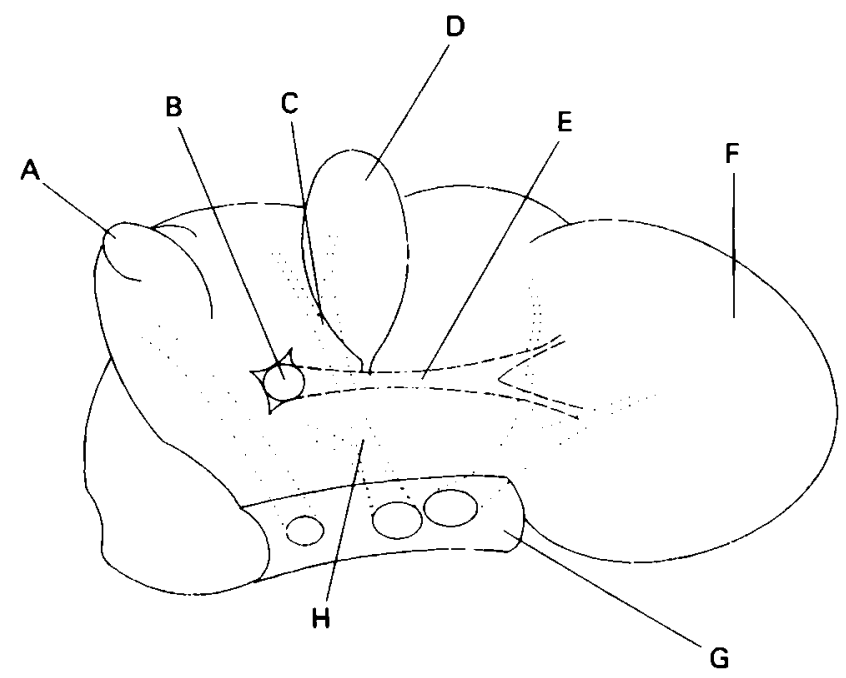

Fig. 2. Schematic view of major hepatic blood vessels of the bovine liver viewed from the visceral surface. $A$, caudate process; $B$, porta hepatis; $C$, insertion point for hepatic vein catheter; $D$, gall bladder; $E$, tip location of portal catheter; F, left lateral lobe; $G$, vena cava; $H$, tip location for hepatic vein catheter.

complete mixing of portal vein blood prior to the porta hepatis, the vein used should not affect data obtained.

Regional differences in the distribution of portal vein blood to the liver have been demonstrated in sheep (Hancock \& Milligan, 1985), but are diminished by rumen development in lambs (Heath \& Perkins, 1985). Laminar flow in the portal vein and regional differences in blood supply to the liver may be of greater concern in cattle which have little, if any, common portal vein prior to the porta hepatis. Indeed, cattle whose portal veins do not enter the liver at a perpendicular angle to the surface of the liver should not be used for splanchnic catheterization studies, because the turbulence which mixes portal blood at the porta hepatis may be reduced (Reynolds et al. 1988a), and portal vein catheter tips should always be introduced well past the porta hepatis and into the left lateral lobe to take advantage of mixing of portal blood at the porta hepatis (Reynolds et al. 1988 a; Huntington et al. 1989). While there is inherent variation in blood flow over time, errors associated with measurement of blood flow are greatly reduced when careful attention is given to placement and immobilization of sampling and PAH infusion catheters (Huntington et al. 1989).

For compounds whose net metabolism by PDV and liver is low relative to their high rates of blood flow, venous-arterial concentration differences are low and difficult to measure. For example, venous-arterial concentration differences across the PDV are quite large for ammonia but extremely small for many individual amino acids. Therefore it is essential that the analytical techniques used are as sensitive and precise as possible, and that within individual studies analytical procedures are strictly adhered to. Variation in patterns of net metabolism over time and sampling protocols must also be carefully considered in applying these techniques for specific experiments. Many researchers feed daily rations in equal meals delivered at frequent intervals to reduce postprandial responses and then sample over shorter time periods, particularly in experiments involving the infusion of labelled substrates for which 'steady state' conditions are required. However, frequent feeding disrupts normal diurnal behaviour patterns, and level of intake and diet digestibility also 
affect postprandial responses. For example, in steers fed every $2 \mathrm{~h}$ a highly digestible, high protein diet at low intakes, postprandial increases in blood flow and ammonia absorption were still dramatic (Maltby, 1993). Higher intakes reduce postprandial responses, but in growing animals assessment of the efficiency of utilization of nutrients requires measurements at varying increments of intake. Researchers must assess sample size, blood volume taken and processing and analytical constraints against sampling frequency, duration and period. Generally, longer sampling periods and slow, frequent sampling reduce error, especially in animals fed once or twice daily (as would occur in production circumstances) or for the study of compounds whose metabolism is subject to inherent variation such as insulin and glucagon (Reynolds et al. 1989). Where characterization of changes in metabolism over short time periods is not needed, integrated sample withdrawal provides the most accurate quantitative estimate of total metabolism (Harris et al. 1992).

\section{ENERGY}

Techniques for estimating tissue oxygen consumption include in vitro incubation of isolated cells or tissue biopsies obtained during experiments by endoscopy and at slaughter in addition to direct measurements of oxygen removal across tissue beds in vivo using animals with indwelling catheters. In vitro techniques are also used to investigate the partitioning of energy expenditure by particular biochemical processes such as $\mathrm{Na}^{+}, \mathrm{K}$ ATPase dependent respiration and protein synthesis through the use of specific metabolic inhibitors (McBride \& Kelly, 1990). These experiments underline the energy requirements of the gastrointestinal tract and liver, which constitute about $10-13 \%$ of total body mass but account for $38-50 \%$ of whole body oxygen consumption (Table 1). Of this total energy expenditure between 28 and $61 \%$ is associated with the maintenance of $\mathrm{Na}^{+}, \mathrm{K}^{+}$-ATPase (EC 3.6.1.3) activity in the gastrointestinal mucosa, 20-23\% with protein synthesis and $4 \%$ with protein degradation (McBride \& Kelly, 1990). Oxygen consumption increases following meal consumption (Christopherson \& Brockman, 1989; Kelly et al. 1989) and changes with level of feed intake (Webster et al. 1975; McBride \& Milligan, 1985; Burrin et al. 1989). The heat increment of feeding has been attributed to several factors including those directly associated with eating, changes in microbial fermentation in the gut, increased metabolic activity in non-intestinal tissues and changes in the metabolic activity of the PDV, the latter being quantitatively the most important in animals fed above maintenance (Webster, 1980).

The relationship between metabolizable energy (ME) intake and PDV heat production, calculated from PDV oxygen consumption using the factor of McLean (1972), is shown in Fig. 3. It is interesting that although there is close correlation between experiments across a wide range of diets, those animals fed diets based on ensiled forages with a higher nondigestible fibrous component tend to produce more PDV heat per unit ME intake than animals fed diets based on concentrates or dried forage. This may be equated to the increased work of digestion related to the physical and chemical nature of the diet, gut fill and changes in the components of ME absorbed (Webster, 1980; Johnson et al. 1990). The expenditure of energy in the physical digestion of feedstuffs is apparent from animals maintained by intragastric infusions (Fig. 3), which had lower rates of PDV oxygen consumption compared with those fed lucerne (Gross et al. 1990a). The small intestines of these animals were empty of digesta and showed considerable tissue atrophy. Similarly, in animals fasted for $65 \mathrm{~h}$ in which the digesta content of the gastrointestinal tract would be temporarily reduced, PDV heat energy was decreased by $43 \%$ to $0.09 \mathrm{MJ} / \mathrm{d}$ per $\mathrm{kg}^{0.75}$ compared with concentrate fed controls (Huntington et al. 1990). This latter figure is 
Table 1. Contribution of gastrointestinal tract and liver to whole body oxygen consumption

\begin{tabular}{|c|c|c|c|}
\hline Tissue & Animal & $\begin{array}{c}\% \text { of whole body } \mathrm{O}_{2} \\
\text { consumption }\end{array}$ & Reference \\
\hline \multirow{7}{*}{$\begin{array}{l}\text { Rumen } \\
\text { Duodenum }\end{array}$} & Steers & $\begin{array}{c}\text { Determinations in vitro } \\
16 \cdot 9-19 \cdot 3\end{array}$ & Kelly et al. (1989) \\
\hline & Cows & & \\
\hline & Dry & $34 \cdot 9$ & McBride \& Milligan (1984) \\
\hline & Lactating & $53 \cdot 8-55 \cdot 0$ & \\
\hline & Sheep & & \\
\hline & Fasted & $28 \cdot 6$ & McBride \& Milligan (1985) \\
\hline & Fed & $48 \cdot 1-61 \cdot 3$ & \\
\hline Jejunum & Steers & $26 \cdot 1 \quad 26 \cdot 2$ & McBride et al. (1989) \\
\hline & & Determinations in vivo & \\
\hline $\mathrm{PDV}^{*}$ & Heifers & $22 \cdot 6-27 \cdot 5$ & Reynolds et al. (1991b) \\
\hline \multirow[t]{2}{*}{ PDV } & Cows & & \\
\hline & Lactating & $17 \cdot 5$ & Huntington \& Tyrrell (1985) \\
\hline \multirow[t]{2}{*}{ PDV } & Cows & & \\
\hline & Lactating & $20 \cdot 0$ & Reynolds et al. (1986) \\
\hline PDV & Steers & $25 \cdot 0$ & Huntington et al. (1989) \\
\hline PDV & Steers & $19 \cdot 8-24 \cdot 0$ & Huntington et al. (1990) \\
\hline \multirow{3}{*}{ PDV } & Steers & & \\
\hline & Fed & $19 \cdot 9-25 \cdot 4$ & Eisemann \& Nienaber (1990) \\
\hline & Fasted & $17 \cdot 8-19 \cdot 9$ & \\
\hline PDV & Steers & $18 \cdot 9-23 \cdot 2$ & Reynolds et al. (1992a) \\
\hline PDV & Sheep & $19 \cdot 0-28.0$ & Burrin et al. (1989) \\
\hline Liver & Heifers & $18 \cdot 5 \cdot 26 \cdot 3$ & Reynolds et al. (1991 b) \\
\hline Liver & Steers & $17 \cdot 5-30 \cdot 9$ & Huntington et al. (1990) \\
\hline \multirow[t]{3}{*}{ Liver } & Steers & & \\
\hline & Fed & $20 \cdot 5-20 \cdot 7$ & Eisemann \& Nienaber (1990) \\
\hline & Fasted & $25 \cdot 2-26 \cdot 4$ & \\
\hline Liver & Steers & $16 \cdot 3-22 \cdot 5$ & Reynolds et al. (1992a) \\
\hline Liver & Sheep & $22 \cdot 0-41 \cdot 0$ & Burrin et al. (1989) \\
\hline
\end{tabular}

* PDV, portal drained viscera.

similar to other data for fasted steers $\left(0.07\right.$ and $0.08 \mathrm{MJ} / \mathrm{d}$ per $\mathrm{kg}^{0.75}$, Eisemann \& Nienaber, 1990), and the intercept value for animals at zero ME intake (Fig. 3) suggests a minimum rate of energy expenditure for tissue maintenance. Comparisons between diets within the same experiment suggest that this maintenance energy requirement may vary with diet composition (Reynolds et al. 1991 b). In this experiment, although increases in PDV oxygen use with greater ME were similar for the two diets, PDV oxygen consumption per unit ME was always greater for heifers fed the higher fibre lucerne diet. Therefore, while the slopes of the two regressions were similar for the two diets, the intercept value was greater when heifers were fed lucerne. This may be attributable in part to increases in gut mass resulting from greater gut fill and perhaps volatile fatty acid (VFA) production and absorption (Reynolds et al. 1993).

High rates of liver oxygen consumption are also attributable to energy costs of ion transport and protein synthesis and degradation. In addition, other processes such as substrate cycling, free radical scavenging, glucose and urea synthesis and detoxification of phenols and other compounds all contribute to liver energy requirements. The exact costs of specific processes are difficult to ascertain, as there is considerable interplay and exchange of metabolic intermediates. For example, the ATP requirement of the urea cycle is lower when the phosphate bonds generated by fumarate metabolism in the tricarboxylic 


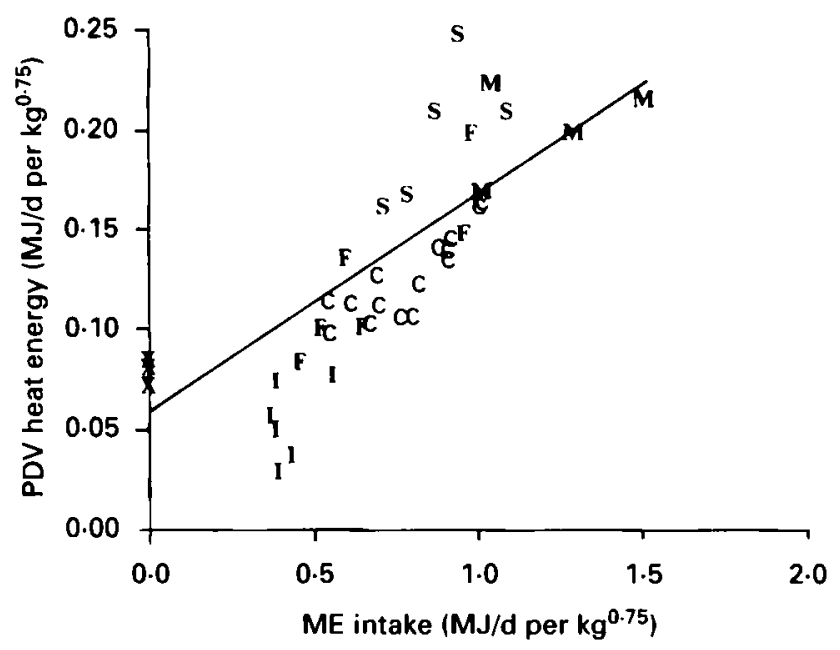

Fig. 3. The relationship between portal drained visceral (PDV) heat energy (MJ/d per $\mathrm{kg}^{0.75}$ ) and metabolizable energy (ME) intake (MJ/d per kg ${ }^{0.75}$ ). (F), > $50 \%$ forage diet; (C), > $50 \%$ concentrate diet; (S), ensiled forage diet; (M), ensiled forage/concentrate mixed diet; (X), fasted animals; (I), animals maintained by intragastric infusion (not included in regression analysis). Each point represents animal means from individual experiments. The equation of the regression line is $y=0 \cdot 059 \pm 0 \cdot 109 x$ $\left(R^{2}=0.612\right)$. Data are from the experiments of Harmon et al. (1988), Huntington $e$ l al. (1988), Reynolds \& Huntington (1988a), Reynolds et al. (1988a,b), Eisemann \& Nienaber (1990), Gross et al. (1990a, b), Huntington et al. (1990), Guerino et al. (1991). Reynolds et al. (1991 b), Reynolds et al. (1992a, b) and Maltby (1993).

acid cycle are considered (Newsholme \& Leach, 1983). It has long been assumed that increases in heat production of cattle resulting from excess protein intake are a direct consequence of the energy costs of urea synthesis (Tyrrell et al. 1970), but in a number of studies in cattle, diet-induced increases in PDV ammonia absorption and liver urea synthesis have not altered liver oxygen use (Reynolds, 1992; Maltby, 1993). However, in each of these studies other changes in PDV nutrient absorption and liver metabolism may have balanced increased oxygen requirements for ureagenesis. In this regard, a recent study found increased body oxygen use resulting from feeding excess protein to beef steers to be due to increases in both PDV and liver oxygen use (Reynolds et al. 1992a).

\section{VOLATILE FATTY ACIDS}

Ruminants absorb little dietary carbon as glucose, even when diets high in starch resistant to rumen fermentation are fed (Bergman et al. 1970; Bergman, 1990). As products of microbial fermentation in the digestive tract, VFA are the primary form in which energy is absorbed into blood by the PDV of ruminants (Baird et al. 1980; Reynolds et al. 1988 ). The contribution of VFA to body energy requirements is even greater when their extensive metabolism by PDV is accounted for. Direct comparisons between VFA production rates and net absorption rates into the portal vein are restricted by the limited amount of data in which both of these variables have been determined in the same animals, due mainly to the complexity of surgical procedures for the implantation of indwelling catheters, which restricts the use of rumen or intestinal cannulae. Alternative approaches must therefore be used, either based on data for rumen VFA production rates measured in animals fed similar 
Table 2. Comparison between rumen volatile fatty acid production rates and net portal absorption rates (moles/d)

\begin{tabular}{|c|c|c|c|c|c|c|c|c|}
\hline \multirow[b]{2}{*}{ Animal } & \multirow[b]{2}{*}{ Diet } & \multicolumn{3}{|c|}{$\begin{array}{l}\text { Rumen production } \\
\text { rate }\end{array}$} & \multicolumn{3}{|c|}{ Portal absorption rate } & \multirow[b]{2}{*}{ Reference } \\
\hline & & A & $\mathbf{P}$ & B & A & $\mathbf{P}$ & $\mathbf{B}$ & \\
\hline \multirow[t]{3}{*}{ Lambs } & Infusion* & $3 \cdot 53$ & 1.94 & 0.32 & $1.88(0.53)^{\dagger}$ & $1.29(0.66)$ & $0.08(0.28)$ & Gross et al. (1990 b) \\
\hline & & 3.27 & $1 \cdot 16$ & 0.31 & $1.97(0.60)$ & $0.81(0.69)$ & $0.08(0.26)$ & \\
\hline & & 3.53 & 0.47 & 0.33 & $1.57(0.44)$ & $0.32(0.67)$ & $0.08(0.26)$ & \\
\hline \multirow[t]{3}{*}{ Lambs } & Infusion & 3.59 & $1 \cdot 11$ & 0.44 & $1.64(0.45)$ & $0.85(0.77)$ & $0.11(0.25)$ & Gross et al. (1990a) \\
\hline & & 3.94 & 1.21 & 0.48 & $1.59(0.40)$ & $0.63(0.52)$ & $0.07(0.14)$ & \\
\hline & & 4.69 & 1.44 & 0.58 & $2.49(0.53)$ & $1.12(0.78)$ & $0.15(0.26)$ & \\
\hline \multirow[t]{2}{*}{ Sheep } & Infusion & & 1.86 & - & - & $1.06(0.57)$ & - & Weekes \& Webster \\
\hline & & & 2.99 & - & - & $1.79(0.59)$ & & $(1975)$ \\
\hline Sheep & Forage & $3 \cdot 3$ & 0.9 & 0.6 & $2 \cdot 3(0 \cdot 69)$ & $0.44(0.49)$ & $0.05(0 \cdot 08)$ & Bergman $(1990)$ \\
\hline Cattle & Concentrate & 16.9 & $6 \cdot 1$ & $4 \cdot 8$ & $9 \cdot 5(0.56)$ & $4.2(0.69)$ & $1 \cdot 1 \quad(0.23)$ & Harmon et al (1988) \\
\hline \multirow[t]{2}{*}{ Steers } & Concentrate & $23 \cdot 7^{\mathrm{a}}$ & $20 \cdot 2$ & 0.9 & $10 \cdot 20(0 \cdot 43)^{b}$ & $8 \cdot 14(0 \cdot 40)$ & $0.6 \quad(0.66)$ & "Sharp et al. (1982) \\
\hline & & & & & & & & $\begin{array}{l}\text { 'Huntington \& } \\
\text { Reynolds (1983) }\end{array}$ \\
\hline \multirow[t]{2}{*}{ Steers } & Forage & $15 \cdot 75$ & $4 \cdot 25$ & - & $7.56(0.48)$ & $1.26(0 \cdot 30)$ & $0 \cdot 31$ & Seal et al. (1992) \\
\hline & Concentrate & $13 \cdot 25$ & $4 \cdot 75$ & - & $6.89(0.52)$ & $1.41(0.30)$ & 0.25 & \\
\hline \multirow[t]{3}{*}{ Steers } & Forage & $7 \cdot 74$ & $3 \cdot 22$ & - & $7.40(0.96)$ & $1.69(0.52)$ & & Seal \& Parker (1993a) \\
\hline & + Propionate & $8-86$ & 3.72 & & $6.52(0.74)$ & $2.09(0.56)$ & - & \\
\hline & + Propionate & $7 \cdot 65$ & $4 \cdot 16$ & - & $5.80(0.76)$ & $2.44(0.58)$ & - & \\
\hline \multirow[t]{6}{*}{ Steers } & Concentrate & - & & 1.58 & - & & $0.74(0.47)$ & Krehbiel et al. (1992) \\
\hline & + Butyrate & - & - & $2 \cdot 78$ & - & & $0.86(0.31)$ & \\
\hline & & & - & 3.98 & - & - & $1.34(0.34)$ & \\
\hline & & & - & $5 \cdot 18$ & & - & $1.63(0.32)$ & \\
\hline & & & - & $6 \cdot 38$ & - & - & $1.90(0.30)$ & \\
\hline & & - & & 7.58 & - & & $2 \cdot 23(0.29)$ & \\
\hline
\end{tabular}

* Intragastric infusion.

+ Values in parentheses, proportion of rumen production rate.

A, Acetate; P, Propionate; B, Butyrate.

-, value not determined.

diets in different experiments, or on theoretical production rates calculated from organic matter digestibilities and observed molar proportions of VFA in rumen fluid. For individual VFA their rate of metabolism by rumen tissue in vitro increases with chain length (Stevens $\&$ Stettler, 1966). The main products of this metabolism are ketone bodies, $\mathrm{CO}_{2}$ and to a lesser extent lactate. Propionate may also be converted into alanine (Bergman, 1990) and, as shown in the rabbit hind gut, acetate carbon may appear in aspartate and glutamate used in protein synthesis (Vernay, 1989). Table 2 shows that $0.31-0.60$ of acetate, $0.22-0.7$ of propionate and $0.34-0.92$ of butyrate produced in the rumen do not appear in the portal vein. Portal appearance rates, however, not only reflect metabolism within the rumen and across the rumen wall, but also include the metabolism of VFA by tissues of the MDV. In sheep, unidirectional absorption of acetate, measured isotopically, represented 0.7 of acetate produced in the rumen and presumably absorbed; however, net PDV absorption of acetate, which includes utilization of arterial acetate, was only 0.5 of rumen production (Bergman \& Wolff, 1971). These relationships were also observed in sheep maintained by intragastric infusion (Table 2) and cattle receiving intraruminal acetate (Huntington et al. 1983). Fermentation of residual carbohydrate flowing to the hind gut may contribute significant quantities of VFA to the portal drainage via the ileocaecal vein (Faichney, 1969; DeGregorio et al. 1984). This latter point is particularly important for the siting of 
indwelling catheters for measurement of metabolism within the mesenteric drained viscera; if the catheter tip is sited caudal to the ileocaecal vein/mesenteric vein junction, net acetate utilization by the MDV may be masked by acetate produced in the large intestine (Seal et al. 1992; Seal \& Parker, 1993b). When MDV flux of beef steers included all the poststomach tissues of the gastrointestinal tract, net flux of acetate across MDV was positive when concentrate was fed, reflecting carbohydrate fermentation in the large intestine and caecum (Owens et al. 1986). When lucerne was fed, net MDV flux of acetate was negative, suggesting that any acetate absorption resulting from microbial fermentation of carbohydrate in the small intestine and caecum was exceeded by MDV utilization of arterial acetate.

Net absorption of VFA across the PDV is highly correlated with the composition of the diet and the level of feed intake (Huntington, 1983; Huntington \& Prior, 1983). However, the proportions of each VFA produced in the rumen which appear in the portal vein remain constant across a wide range of different diets. Absolute absorption rates increase during lactation (Stangassinger \& Giesecke, 1986) in parallel with increased feed intake, but despite the increase in gut and liver tissue mass associated with lactation (Campbell \& Fell, 1970; Fell et al. 1972; Fell \& Weekes, 1975) there is little change in the relative proportions of VFA absorbed into the portal vein. Changing rumen fermentation pattern by altering the forage:concentrate ratio of the diet or by infusions of individual VFA may alter the pattern of VFA absorbed, but the extent of metabolism of the fatty acids remains constant (Krehbiel et al. 1992; Seal et al. 1992; Seal \& Parker, 1993b). Recent experiments from Peters et al. (1990) have suggested that over a wide range of rumen propionate production rates approximately 0.66 of available propionate disappeared from within the rumen (presumed to be absorbed) and 0.34 passed from the rumen to the lower tract in the liquid phase. These data suggest that at least some of the apparent shortfall in VFA appearing in the portal vein may be attributed to metabolism within abomasal and omasal tissues in addition to that lost across the rumen wall.

Excluding acetate, the liver removes $85-100 \%$ of VFA appearing across PDV on a net basis (Reynolds et al. 1988 b). Therefore, acetate is the only VFA present in peripheral blood in substantial quantities and represents an important energy substrate for peripheral and PDV tissues. Net acetate flux across liver is usually slightly positive, but net measurements can mask simultaneous unidirectional uptake and release of acetate by the ruminant liver (Bergman \& Wolff, 1971), which are perhaps due to zonal heterogeneity of liver metabolism as described for non-ruminants (Katz, 1992). In the liver, VFA removed contributes carbon for glucose and 3-hydroxybutyrate synthesis, and precursors of acetylCoA provide carbon which can enter a number of metabolic pathways. In the fed state the ruminant liver removes acetoacetate and produces 3-hydroxybutyrate, with $n$-butyrate contributing $26-48 \%$ of carbon in the 3-hydroxybutyrate produced (Lomax \& Baird, 1983; Reynolds et al. 1988 b, 199(a). Other sources of carbon for 3-hydroxybutyrate release include acetoacetate produced by PDV (Heitmann et al. 1986) and the oxidation of nonesterified fatty acids extracted from portal vein and arterial blood (Bell, 1979). In fasted animals the liver flux of acetoacetate switches from removal to release, and the contribution of $n$-butyrate to ketone body production decreases and its absorption by PDV and the contribution of non-esterified fatty acids to liver ketone body production rises (Heitmann et al. 1986). As for acetate, 3-hydroxybutyrate is a source of oxidizable substrate for extrahepatic tissues.

Propionate is the principal source of carbon for glucose synthesis in liver, which meets $85-90 \%$ of body glucose requirements in sheep (Bergman et al. 1970). Assuming a maximal use of propionate removed by liver for glucose synthesis, propionate accounts for $32-73 \%$ of liver glucose release (Table 3 ). Theoretical calculations addressing carbon randomization 
Table 3. Maximal net contributions of precursors removed to glucose released $(\mathrm{mmol} / \mathrm{h})$ by ruminant liver

\begin{tabular}{|c|c|c|c|c|c|c|}
\hline \multirow[b]{2}{*}{ Animal } & \multirow[b]{2}{*}{ Diet } & \multirow[b]{2}{*}{$\begin{array}{l}\text { Glucose } \\
\text { release }\end{array}$} & \multicolumn{3}{|c|}{ Percentage of net glucose release } & \multirow[b]{2}{*}{ Reference } \\
\hline & & & Propionate & $\begin{array}{l}\text { Amino } \\
\text { acids }\end{array}$ & L-Lactate & \\
\hline Mature sheep & Lucerne & $21 \cdot 7$ & $40 \cdot 3$ & 29.0 & & $\begin{array}{l}\text { Bergman et al. }(1970) \\
\text { Bergman \& Wolf (1971); } \\
\text { Wolff \& Bergman (1972) }\end{array}$ \\
\hline Growing steers & Concentrate & 180 & $72 \cdot 8$ & $12 \cdot 1$ & $13 \cdot 1$ & $\begin{array}{l}\text { Huntington \& Eisemann } \\
\text { (1988) }\end{array}$ \\
\hline \multirow{6}{*}{$\begin{array}{l}\text { Growing steers } \\
\text { Growing steers }\end{array}$} & Fescue hay & 147 & $46 \cdot 3$ & $21 \cdot 4$ & $10 \cdot 9$ & Harmon et al. (1991b) \\
\hline & Concentrate & & & & & \\
\hline & Low intake, saline & 123 & 58.5 & 11.6 & $10 \cdot 7$ & \multirow{4}{*}{$\begin{array}{l}\text { Reynolds et al. }(1992 b) \\
\text { Reynolds et al. }(1992 a)\end{array}$} \\
\hline & Low intake + GRF & 105 & $56 \cdot 1$ & $5 \cdot 8$ & $14 \cdot 2$ & \\
\hline & High intake, saline & 245 & 53.9 & $15 \cdot 1$ & 1.4 & \\
\hline & High intake + GRF & 237 & 67.3 & $13 \cdot 2$ & 1.6 & \\
\hline Growing steers & Concentrate: hay & 116 & $52 \cdot 6$ & $28 \cdot 4$ & $44 \cdot 0$ & Krehbiel el al. (1992) \\
\hline Growing steers & Lucerne & 227 & $42 \cdot 5$ & $19 \cdot 6$ & $15 \cdot 0$ & Harmon et al. (1993) \\
\hline Mature steers & Concentrate & 190 & $32 \cdot 2$ & $20 \cdot 0$ & 9.9 & Reynolds et al. (1992c) \\
\hline \multirow[t]{6}{*}{ Growing heifers } & Lucerne & & & & & \multirow{6}{*}{$\begin{array}{l}\text { Reynolds et al. }(1991 b) \\
\text { Reynolds et al. }(1993 b)\end{array}$} \\
\hline & Low intake & 119 & $52 \cdot 2$ & $32 \cdot 4$ & $7 \cdot 0$ & \\
\hline & High intake & 263 & 59.9 & $35 \cdot 3$ & $9 \cdot 3$ & \\
\hline & Concentrate & & & & & \\
\hline & Low intake & 116 & $46 \cdot 6$ & $23 \cdot 9$ & $9 \cdot 1$ & \\
\hline & High intake & 285 & $59 \cdot 8$ & $24 \cdot 6$ & 1.9 & \\
\hline \multirow[t]{2}{*}{ Mature heifers } & Forage & 192 & $75 \cdot 8$ & $26 \cdot 0$ & $8 \cdot 2$ & \multirow{5}{*}{$\begin{array}{l}\text { Reynolds \& Tyrrell (1991) } \\
\text { Reynolds et al. (1991 a) } \\
\text { Baird et al. (1980) } \\
\text { Lomax \& Baird (1983) }\end{array}$} \\
\hline & Concentrate & 214 & $59 \cdot 6$ & $23 \cdot 5$ & 6.6 & \\
\hline Lactating cows & Ad libitum & 392 & $52 \cdot 8$ & & $22 \cdot 9$ & \\
\hline Lactating cows & Ad libitum & 325 & 46.0 & & 16.0 & \\
\hline Dry cows & Restricted & 240 & $56 \cdot 6$ & & $10 \cdot 6$ & \\
\hline Lactating cows & Ad libitum & 713 & $55 \cdot 4$ & 16.5 & 17.5 & Reynolds et al. (1988b) \\
\hline
\end{tabular}

GRF, growth hormone releasing factor.

during isotope transfer studies suggest that almost all of the propionate removed by liver is used in glucose synthesis (Armentano, 1992).

\section{AMINO ACIDS AND PEPTIDES}

Mechanisms for the uptake and transport of amino acids and peptides have been extensively reviewed (Webb \& Bergman, 1991; Webb et al. 1992), and these have received added attention with the use of improved analytical techniques for the determination of free amino acids and low molecular weight peptides in plasma. Although limited by the number of animals used in the experiment, Tagari \& Bergman (1978) clearly demonstrated that the quantity of amino acids appearing in the portal blood of sheep did not balance the amount disappearing from the intestinal lumen, and this report and various others since have suggested that between 30 and $80 \%$ of amino acids disappearing from the lumen do not appear in the portal vein. In steers given postruminal casein (Guerino et al. 1991) only $28 \%$ of the casein nitrogen infused abomasally appeared in the portal blood as $\alpha$-amino nitrogen. Piccioli Cappelli et al. $(1993 \mathrm{~b})$ similarly demonstrated that up to $48 \%$ of $\left[{ }^{13} \mathrm{C}\right]$ leucine infused directly into the duodenum of sheep could not be recovered in the portal vein when measured on a net transfer basis. However, if the sequestration of arterial ${ }^{13} \mathrm{C}$ tracer by the gut tissues is taken into account, recovery of $\left[{ }^{13} \mathrm{C}\right]$ leucine administered to the small intestine may be nearer $70 \%$ (MacRae et al. 1993). High rates of protein turnover 


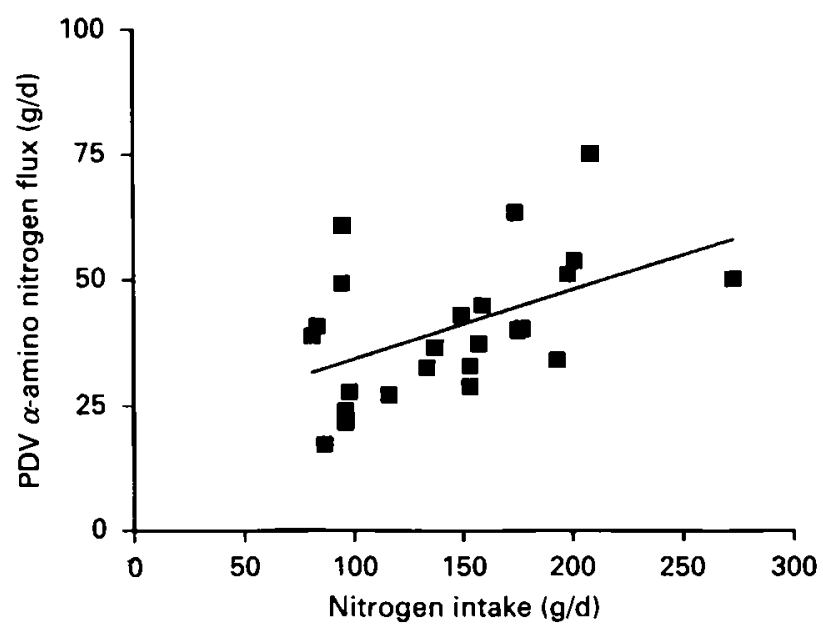

Fig. 4. The relationship between portal drained visceral (PDV) flux of $\alpha$-amino nitrogen in whole blood $(\mathrm{g} / \mathrm{d})$ and nitrogen intake $(\mathrm{g} / \mathrm{d})$. Each point represents animal means from individual experiments. The equation of the regression line is $y=20.429 \pm 0.136 x\left(R^{2}=0.235\right)$. Data are from the experiments of Harmon et al. (1988), Huntington et al. (1988). Reynolds \& Huntington (1988a), Eisemann \& Nienaber (1990), Guerino et al. (1991), Reynolds et al. (1991 c), Reynolds \& Tyrrell (1991), Reynolds et al. (1992 b) and Harmon et al. (1993).

within the gastrointestinal tract, together with the use of amino acids as energy substrates within the mucosa, are cited as possible fates of those amino acids lost across the gut wall, substantially affecting the pattern of amino acids available to the liver and peripheral tissues (Lobley et al. 1980). Gut protein synthesis rates vary with feed intake and physiological state (see for example Baracos et al. 1991) and change during postnatal growth and development (Reeds et al. 1993). Glutamine, glutamate and aspartate have been shown to be important fuels in rat intestinal tissues (Windmueller \& Spaeth, 1978, 1980). Unidirectional utilization of glutamate and glutamine by PDV in sheep (Heitmann \& Bergman, 1981) and net extraction by PDV of cattle (Huntington, 1983; Wilton, 1989) suggests that this may also be the case in ruminant gut tissues; however, venous-arterial concentration differences for glutamine are consistently smaller in these species compared with the rat (C. J. Seal \& D.S. Parker, unpublished observations). Net glutamine utilization by the MDV in forage-fed steers compared with animals fed a diet containing $50 \%$ flaked maize (Seal et al. 1992) and similar responses across the PDV of steers when switched from forage to concentrate diets (Reynolds \& Huntington, 1988a) indicate that amino acid metabolism within the gut tissues alters in these different dietary situations.

Measurements of net PDV $\alpha$-amino nitrogen flux over a wide range of nitrogen intakes and different diets (Fig. 4) suggest that amino acid release by PDV is not correlated with dietary nitrogen supply. Within individual experiments it has been suggested, however, that net $\alpha$-amino nitrogen release by PDV is correlated with ME intake (Huntington et al. 1988; Huntington, 1989; Reynolds et al. 1991 b), the principal determinant of microbial protein synthesis and therefore duodenal protein flow (Clark et al. 1992). However, comparisons between experiments again show poor correlation, perhaps due to differences between experiments in sample processing and analytical techniques (Maltby, 1993). This confirms the complex interaction between gastrointestinal tissues and the diet, which may be a direct response to changes in gut energy expenditure or patterns of rumen fermentation. Changing propionate supply by intraruminal infusion of propionic acid in steers resulted in higher circulating amino acid levels and elevated net absorption rates of amino acids 
across the MDV and PDV (Seal \& Parker, 1991a). Subsequent experiments with cannulated sheep infused with propionate (Seal et al. 1993a) showed that these responses were not associated with changes in overall nitrogen digestibility or alterations in rumen microbial metabolism and the flow of microbial nitrogen into the small intestine. Circulating amino acid levels were also increased in these animals, and the results imply that amino acid utilization within the intestinal tissues had been reduced as a direct response to increased ruminal propionate availability. In contrast, Harmon (1991) showed that increased butyrate availability in animals maintained by intragastric infusion reduced net PDV $\alpha$-amino nitrogen flux. A similar response was observed in steers (Krehbiel et al. 1992), where increasing ruminal butyrate tended to lower PDV $\alpha$-amino nitrogen flux. It was suggested that this was due to increased tissue amino acid requirements in response to the known trophic stimulus of butyrate (Sakata \& Tamate, 1978).

The studies of Bergman and co-workers have demonstrated both net and unidirectional metabolism of individual amino acids by liver of sheep, as well as the impact of fasting, acidosis and hormonal manipulation on splanchnic amino acid metabolism (for reviews see Bergman \& Heitmann, 1978; Bergman \& Pell, 1984; Bergman, 1989). Most amino acids are removed on a net basis by the liver, reducing the availability to other body tissues of amino acids absorbed across PDV. Exceptions include the branched chain amino acids and glutamate, which are usually released by liver. These studies also identified a number of interorgan amino acid cycles for which the liver is a central player. Participants include glutamate and glutamine, glycine and alanine and also arginine, ornithine and citrulline. These cycles shuttle carbon and nitrogen between the liver - as a site of glucose, protein and urea synthesis - and peripheral tissues - as sites of glucose utilization and protein synthesis and turnover. Nitrogen arising from the catabolism of amino acids in peripheral tissues is carried to the liver as alanine, glycine or glutamine for urea synthesis, avoiding excessive release of potentially toxic ammonia into the peripheral circulation. Alanine, glycine and urea cycle intermediates serve the same function for nitrogen arising from amino acid catabolism in PDV tissues.

Metabolism of glutamine, glutamate and urea show zonal heterogeneity in non-ruminant liver, with glutamine uptake, urea synthesis and glutamate synthesis more active in periportal cells, and glutamine synthesis and glutamate uptake more active in pericaval cells (Häussinger, 1983). Simultaneous unidirectional release and uptake of glutamate and glutamine in sheep liver (Heitmann \& Bergman, 1981) imply a similar zonal heterogeneity in this species, but to date studies of zonal heterogeneity have not been conducted for ruminant liver. On a net basis the ruminant liver releases glutamate and removes glutamine. Glutamate is an important source of nitrogen for liver ureagenesis, supplying one or two nitrogens in urea via aspartate, and increases in liver urea production are often associated with decreases in liver glutamate release (Reynolds, 1992).

Amino acids removed by liver represent important precursors for glucose and protein synthesis (Table 3). Their exact contribution to glucose synthesis has been difficult to determine precisely, in part due to the problems of label randomization in carbon exchange studies, but total gluconeogenic amino acid removal maximally accounted for $30 \%$ of liver glucose release in maintenance fed sheep (Wolff \& Bergman, 1972), which is within the range of theoretical net contributions calculated from measured extraction of amino acids across the liver (Table 3). The liver has a pivotal role in the integration of body nutrient requirements with nutrient supply from the PDV. In beef steers receiving abomasal infusions of casein, increased PDV absorption of $\alpha$-amino nitrogen was matched by increased liver removal such that there was little change in splanchnic release of total amino acids and a marked increase in liver urea synthesis and urinary nitrogen excretion (Guerino et al. 1991). However, when body nitrogen retention of beef steers was doubled by growth 
hormone releasing factor injections, liver $\alpha$-amino nitrogen removal was reduced, sparing absorbed amino acids for protein synthesis in peripheral tissues (Reynolds et al. $1992 \mathrm{~b}$ ). Changes in liver amino acid removal were accompanied by decreased liver urea production, a decrease in the cycling of ammonia and urea between PDV and liver, and decreased urinary nitrogen excretion. The impact of liver metabolism on the availability of absorbed amino acids was also apparent in steers fed rumen protected methionine and lysine (Maltby et al. 1991). Increased PDV absorption of these amino acids was matched by their liver removal and therefore there was no change in their total splanchnic release to peripheral tissues.

Speculation about the apparent loss of amino acids across the gut tissues has generated renewed interest in the possible contribution of peptide bound amino acids (PBAA) to the total $\alpha$-amino nitrogen flux. The absorption of intact peptides across the gastrointestinal barrier in vivo is not well documented, although there is considerable in vitro information which supports the notion of specific transport mechanisms for the uptake of peptides into the enterocyte (Webb \& Bergman, 1991). Net PDV release (positive venous -arterial concentration differences) of PBAA as measured with hydrolysed sulphosalicylic acid supernatants has been shown in steers and sheep (Koeln \& Webb, 1982; Read, 1988; Webb et al. 1993) and in perchloric acid supernatants separated by HPLC from rat plasma (Seal \& Parker, $1991 b$ ). Concentrations of PBAA measured in this way (4.0-6.8 mM (McCormick \& Webb, 1982; Danilson et al. 1987); 3.3 3.9 mM (Read, 1988); 3.8-6.1 mm (Seal \& Parker, $1991 b)$ ) exceeded plasma free amino acid concentrations two- to three-fold, and relative concentrations were different between ruminant and non-ruminant species (Seal \& Parker, $1991 \mathrm{~b}$ ). Recent work from the Newcastle group has involved the use of molecular weight filters (Millipore Corporation, Milford, MA) to remove large proteins from plasma. Whilst the concentrations of free amino acids in filtrates were similar to those measured in acid supernatants, the corresponding PBAA levels in filtrates separated by HPLC were much lower (Seal \& Parker, 1993 b), suggesting that acid treatment of plasma samples may produce higher apparent PBAA levels, either through residual oligopeptides/small proteins remaining in supernatants or by the 'production' of small peptides through partial acid hydrolysis of labile plasma proteins. Net PBAA release across the mesenteric and portal drained viscera calculated from these data averaged 1.76 and $3.02 \mathrm{mmol} / \mathrm{min}$ respectively. PBAA release by the non-mesenteric tissues (P-M, $1.26 \mathrm{mmol} / \mathrm{min}$ ) was in contrast to removal of free amino acids by these tissues $(-0.99 \mathrm{mmol} / \mathrm{min})$, suggesting net output of PBAA but not free amino acids from large intestinal, stomach and proximal small intestinal tissues. Webb et al. (1993) have recently suggested that ruminal and omasal epithelia incubated in vitro have the capacity to transport small peptides, and the same group present data showing positive non-mesenteric flux of peptides in sheep and steers. Despite numerous publications suggesting the potential of ruminant gastrointestinal tissues to absorb peptides, there is no direct evidence that luminally derived peptides are absorbed intact across the gut wall in vivo or that PBAA appearing in the portal drainage are solely of dietary origin - the high rates of protein turnover within gut tissues may also contribute a significant amount of peptide material to this pool. The contributions of plasma protein pools and peptides to PDV and liver nitrogen and carbon exchange need to be defined and quantified.

\section{AMMONIA AND UREA}

Non-protein nitrogen in the form of ammonia and urea form an important route through which nitrogen is recycled and conserved in the ruminant animal. Net PDV ammonia nitrogen flux is highly correlated with dietary nitrogen intake (Fig. 5) and especially 


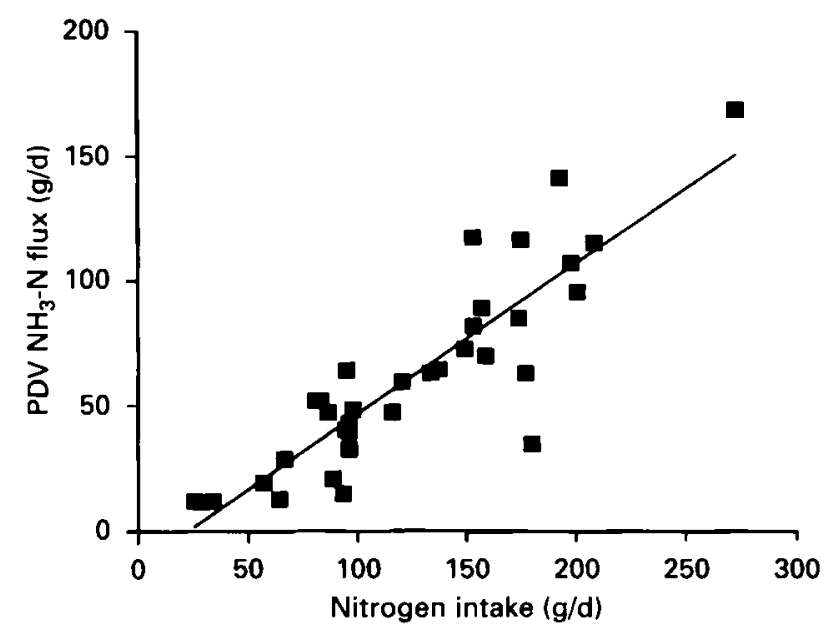

Fig. 5. The relationship between portal drained visceral (PDV) flux of ammonia nitrogen (g/d) and nitrogen intake $(\mathrm{g} / \mathrm{d})$. Each point represents animal means from individual experiments. The equation of the regression line is $y=-12.96 \pm 0.594 x\left(R^{2}=0.772\right)$. Data are from the experiments of Wolff et al. (1972), Sniffen \& Jacobson (1975), Huntington (1983), Huntington \& Prior (1983), Harmon et al. (1988), Huntington et al. (1988), Reynolds \& Huntington (1988a), Eisemann \& Nienaber (1990), Guerino et al. (1991), Reynolds et al. (1991 c), Reynolds \& Tyrrell (1991), Reynolds et al. (1992 b), Seal et al. (1992) and Harmon et al. (1993).

digestible nitrogen intake (Reynolds et al. 1991c, 1992a); it can account for as much as $65 \%$ of nitrogen intake, and under normal circumstances is at least equal to and usually exceeds $\alpha$-amino nitrogen absorption rates (Huntington, 1986). Quantities of ammonia absorbed by PDV are determined not only by intake of digestible nitrogen but also by the nature of the carbohydrate and protein consumed. All ammonia absorbed by PDV is subsequently removed by liver so that splanchnic flux is very low or negative; however, other routes of ammonia absorption from the gut have been identified (Chalmers et al. 1971). Ammonia removed by the liver is converted into urea or used in other synthetic pathways. Ammonia absorbed across the PDV is derived in part from urea transferred into the gut lumen, and a substantial cycling of urea and ammonia between the PDV and liver occurs in ruminants (Huntington, 1986). In growing cattle fed diets high in rumen soluble nitrogen, excessive ammonia absorption has been associated with increased net removal of amino acids by liver (Huntington, 1989; Reynolds et al. 1991 c). This response has been attributed to an increase in urea cycle requirements for cytosolic aspartate and glutamate, which cannot be met by mitochondrial capture of ammonia as glutamate (Reynolds, 1992); however, recent studies have failed to repeat this effect of ammonia uptake on liver amino acid removal (Reynolds et al. $1992 a$; Maltby, 1993). This response has been observed primarily in younger animals at higher ME intakes, and the variability of the response across studies may relate to the interactions between protein requirements and the availability of labile protein pools (Elwyn, 1970).

\section{GLUCOSE}

Under normal dietary conditions for ruminants fed a mixed diet, the levels of glucose available for absorption in the small intestine are low, and the contribution of absorbed glucose to whole body glucose supply is minimal. When diets contain high levels of cereal grain, and in particular ground maize, there is evidence that significant quantities of starch 
Table 4. Comparison between whole body glucose turnover rate and net portal glucose utilization rate

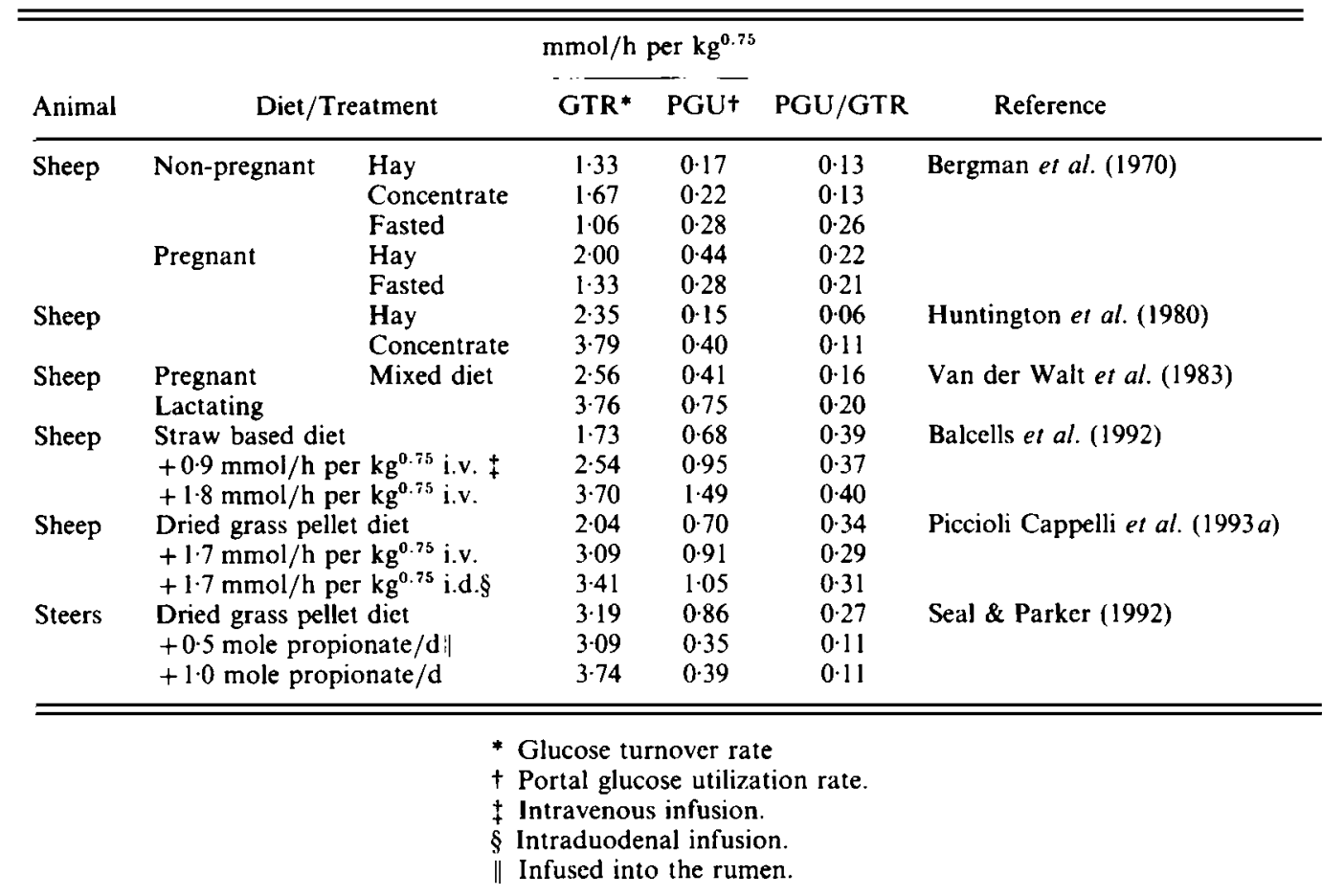

may escape rumen fermentation and pass into the duodenum (Waldo, 1973; Armstrong \& Smithard, 1979; Rooney \& Pfugfelder, 1986). Despite suggestions that small intestinal starch digestion may be limited by low levels of enzyme activity and adequate access of enzymes to starch granules (Owens et al. 1986), substantial quantities of starch disappearing in the small intestine with digestibilities ranging from 10 to $96 \%$ have been reported (Harmon, 1992). Recovery of abomasally infused glucose and corn starch in beef steers averaged $65 \%$ of the glucose and $35 \%$ of the starch as increased glucose absorption into portal blood (Huntington \& Reynolds, 1986). Kreikemeier et al. (1991) have also demonstrated lower recoveries of starch glucose in the portal vein from abomasal infusions of corn starch compared with equivalent infusions of glucose. A recent experiment with growing steers fed lucerne in which potato starch was infused directly into the duodenum (Seal et al. 1993b) showed that these forage-fed animals were able to hydrolyse starch very rapidly, and that plasma glucose levels were elevated within one hour of presenting starch to the intestine. Recovery of starch glucose in the portal vein averaged $84 \%$ and was not increased by the third day of a continuous starch infusion. The higher recovery of glucose may be due to differences in the chemical structure of the potato starch used in this experiment compared with previous work using corn starch (Nocek \& Tamminga, 1991), but the results clearly demonstrate the capacity of the small intestine to absorb significant quantities of glucose if present in the gut lumen, despite the suggestion that during development of the enterocyte the $\mathrm{Na}^{+}$-glucose cotransporter is regulated by the presence of sugar substrate in the lumen (Shirazi-Beechey et al. 1991 a). This is in agreement with the suggestion of Mayes \& Ørskov (1974) that it is the capacity to hydrolyse starch rather than to absorb glucose which is limiting in ruminants. 
Measurements of net glucose absorption by MDV and PDV in ruminants consuming forages generally show a net extraction (i.e. negative venous-arterial concentration difference) of glucose by the digestive tract compared with those fed concentrates for which net uptake may be observed (Parker, 1990). These studies do not consider the effect of glucose metabolism within the gut tissues, and reflect the overall balance of absorption and utilization across the tissue bed. Net glucose utilization rates, which reflect the metabolic requirement of intestinal tissues, determined by comparison of glucose-specific radioactivity in arterial and venous blood (Bergman et al. 1970), show that on average portal utilization of arterial glucose accounts for about $22 \%$ of whole-body glucose turnover (Table 4 ). Within individual experiments, increasing the glucose turnover rate causes a proportionate increase in glucose utilization by the PDV, except for animals receiving intraruminal propionate (Seal \& Parker, 1992), where portal glucose utilization was significantly reduced by exogenous propionate. The results indicate that glucose utilization responds to increased glucose supply, and that this requirement may be met from both vascularly and luminally derived substrate (Piccioli Cappelli et al. 1993a). Manipulation of starch availability to the small intestine, and the consequences that this may have on glucose metabolism within the gut tissues and the use of other energy-yielding substrates, is clearly an area requiring further investigation.

\section{SUMMARY}

In conclusion, the splanchnic tissues have a profound impact on the supply of nutrients for maintenance and production in ruminants. Their metabolism accounts for a substantial portion of maintenance costs, but in a manner which varies with diet composition and intake level. Specific details of the quantitative and structural impact of gut and liver metabolism on absorbed nutrients and the integration of this metabolism with nutrients produced by other body tissues have resulted from in vivo studies utilizing multicatheterization techniques. The judicious use of these techniques should further our quantitative understanding of how diet affects nutrient supply for productive processes such as growth or lactation. In the future, nutritionists may be able to formulate diets to meet the nutritional requirements of specific tissues, including the gut and liver. Changes in the quantity and pattern of nutrients available to the splanchnic bed influence the distribution of nutrients to the body. While it may appear that these tissues compete with other tissues for absorbed nutrients, their metabolism is in fact integrated with the metabolism of peripheral tissue and supportive of changes in requirements of all body tissues.

\section{REFERENCES}

Aiello, R. J., Armentano, L. E., Bertics, S. J. \& Murphy, A. T. (1989). Volatile fatty acid uptake and propionate metabolism in ruminant hepatocytes. Journal of Dairy Science 72, 942-949.

Armentano, L. E. (1992). Ruminant hepatic metabolism of volatile fatty acids, lactate and pyruvate. Journal of Nutrition 122, 838-842.

Armstrong, D. G. \& Smithard. R. R. (1979). The fate of carbohydrates in the small and large intestines of the ruminant. Proceedings of the Nutrition Society 38, $283-294$.

Baird, G. D., Lomax, M. A., Symonds, H. W. \& Shaw, S. R. (1980). Net hepatic and splanchnic metabolism of lactate, pyruvate and propionate in dairy cows in vivo in relation to lactation and nutrient supply. Biochemical Journal 186, 47-57.

Balcells, J, Seal, C. J. \& Parker, D. S. (1992). Effect of intravenous glucose infusion on glucose metabolism by portal drained viscera of sheep fed a low quality roughage. Journal of Animal Science 70 (Suppl. 1), 294.

Baldwin, R. L. \& Jesse, B. W. (1992). Developmental changes in glucose and butyrate metabolism by isolated sheep ruminal cells. Journal of Nutrition 122, 11491153.

Baldwin, R. L. \& Jesse, B. W. (1993). Metabolic interaction of propionate with ketone production by isolated rumen epithelial cells. Journal of Animal Science 71 (Suppl. 1), 270. 
Baracos, V. E., Brun-Bellut. J. \& Marie. M. (1991). Tissue protein synthesis in lactating and dry goats. British Journal of Nutrition 66, 451-465.

Bell, A. W. (1979). Lipid metabolism in liver and selected tissues and in the whole body of ruminant animals. Progress in Lipid Research 18. 117-164.

Bergman, E. N. (1975). Production and utilization of metabolites by the alimentary tract as measured in portal and hepatic blood. In Digestion and Metabolism in the Ruminant, pp. 292-305 [I. W. McDonald \& A. C. I. Warner, editors]. Armidale, Australia: University of New England Publishing Unit.

Bergman, E. N. (1989). Splanchnic and peripheral uptake of amino acids in relation to the gut. Federation Proceedings 45, 2277-2282.

Bergman, E. N. (1990). Energy contributions of volatile fatty acids from the gastrointestinal tract in various species. Physiological Reviews 70, 567-590.

Bergman, E. N. \& Heitmann, R. N. (1978). Metabolism of amino acids by the gut, liver, kidneys and peripheral tissues. Federation Proceedings 37, $1228-1232$.

Bergman, E. N., Katz, M. L. \& Kaufman, C. F. (1970). Quantitative aspects of hepatic and portal glucose metabolism and turnover in sheep. American Journal of Physiology 219, 785-793.

Bergman, E. N. \& Pell, J. M. (1984). Integration of amino acid metabolism in the ruminant. In Herbivore Nutrition in the Subtropics and Tropics, pp. 613-628 [F. M. C. Gilchrist \& R. I. Mackie, editors]. Craighall, Johannesburg, South Africa: Science Press.

Bergman, E. N. \& Wolff, J. E. (1971). Metabolism of volatile fatty acids by liver and portal drained viscera in sheep. American Journal of Physiology 221, 586-592.

Bradley, S. E., Ingelfinger, F. J., Bradley, C. P. \& Curry, J. J. (1945). The estimation of hepatic blood flow in man. Journal of Clinical Investigation 24, 890-897.

Brown, G. F., Armstrong, D. G. \& MacRae, J. C. (1968). The establishment in one operation of a cannula into the rumen and re-entrant cannulae into the duodenum and ileum of the sheep. British Veterinary Journal 124. $78-82$.

Burrin, D. G., Ferrell, C. L., Eisemann, J. H., Britton, R. A. \& Nienaber, J. A. (1989). Effect of level of nutrition on splanchnic blood flow and oxygen consumption in sheep. British Journal of Nutrition 62, 23.34.

Campbell, R. M. \& Fell, B. F. (1970). Observations on hypertrophy of the liver in breeding ewes. Research in Veterinary Science 11, $540-547$.

Carr, S. B. \& Jacobson, D. R. (1968). Method for measurement of gastrointestinal absorption in normal animals, combining portal-carotid differences and telemetered portal flow by Doppler shift. Journal of Dairy Science $\mathbf{5 1}$, 721-729.

Chalmers. M. I., Jaffray, A. E. \& White, F. (1971). Movements of ammonia following intraruminal administration of urea or casein. Proceedings of the Nutrition Society 30, 7-17.

Christensen, H. N. (1990). Role of amino acid transport and countertransport in nutrition and metabolism. Physiological Review's 70, 43-77.

Christopherson, R. J. \& Brockman, R. P. (1989). Effect of feeding and a $\beta$-adrenergic blocking agent on oxygen consumption by the portal drained viscera, liver and hind quarters of the sheep. In Energy Metabolism of Farm Animals (EAAP Publication No. 43), pp. 147-150 [Y. Van der Honing \& W. H. Close, editors]. Wageningen, Netherlands: Centre for Agricultural Publishing and Documentation (Pudoc).

Clark, J. H., Klusmeyer, T. H. \& Cameron, M. R. (1992). Microbial protein synthesis and flows of nitrogen fractions to the duodenum of dairy cows. Journal of Dairy Science 75, 2304-2323.

Conrad, H. R., Smith, H. R., Vandersall, J. H., Pounden, W. D. \& Hibbs, J. W. (1958). Estimating gastrosplenic blood flow and volatile fatty acid absorption from the forestomachs of calves. Journal of Dairy Science 41 , $1094-1099$.

Crane, R. K. \& Wilson, T. H. (1958). In vitro method for the study of the rate of intestinal absorption of sugars. Journal of Applied Physiology 12, 145- 146.

Danilson, D. A., Webb, K. E. \& Herbein, J. H. (1987). Transport and hindlimb exchange of peptide and serum protein amino acids in calves fed soy- or urea-based purified diets. Journal of Animal Science 64, $1852-1857$.

DeGregorio, R. M., Tucker, R. E., Mitchell, G. E. \& Gill, W. W. (1984). Acetate and propionate production in the cecum and proximal colon of lambs. Journal of Animal Science 58, 203 -207.

Durand, D., Bauchart, D., LeFaivre, J. \& Donnat, J. P. (1988). Method for continuous measurement of blood metabolite hepatic balance in conscious preruminant calves. Journal of Dairy Science 71, 1632-1637.

Eisemann, J H. \& Nienaber, J. A. (1990). Tissue and whole-body oxygen uptake in fed and fasted steers. British Journal of Nutrition 64, 399-411.

Elwyn, D. H. (1970). The role of the liver in regulation of amino acid and protein metabolism. In Mammalian Protein Metabolism, Vol. 4, pp. 523-557 [H. N. Munro, editor]. New York: Academic Press.

Faichney, G. J. (1969). Production of volatile fatty acids in the sheep caecum. Australian Journal of Agricultural Research 20, 491- 498.

Faulkner, A. \& Pollock, H. T. (1990). Effects of glucagon and $\alpha$ - and $\beta$-agonists on glycogenolysis and gluconeogenesis in isolated ovine hepatocytes. Biochimica et Biophysica Acta 1052, 229-234.

Fell, B. F., Campbell, R. M., Mackie, W. S. \& Weekes, T. E. C. (1972). Changes associated with pregnancy and lactation in some extra-reproductive organs of the ewe. Journal of Agricultural Science 79, 397-407.

Fell, B. F. \& Weekes, T. E. C. (1975). Food intake as a mediator of adaptation in the ruminal epithelium. In 
Digestion and Metabolism in the Ruminant, pp. $101-118$ [I. W. McDonald \& A. C. I. Warner, editors]. Armidale, NSW, Australia: University of New England Publishing Unit.

Gross, K. L., Harmon, D. L. \& Avery, T. B. (1990a). Portal-drained visceral flux of nutrients in lambs fed alfalfa or maintained by total intragastric infusion. Journal of Animal Science 68, 214-221.

Gross, K. L., Harmon, D. L., Minton, J. E. \& Avery, T. B. (1990 b). Effects of isoenergetic infusions of propionate and glucose on portal-drained visceral nutrient flux and concentrations of hormones in lambs maintained by total intragastric infusion. Journal of Animal Science 68, 2566- 2574.

Guerino, F., Huntington, G. B. \& Erdman, R. A. (1991). The net portal and hepatic flux of metabolites and oxygen consumption in growing beef steers given postruminal casein. Journal of Animal Science 69, 387-395.

Hancock, M. J. \& Milligan, L. P. (1985). Distribution of portal blood to the liver of sheep. Journal of Animal Science 61 (Suppl. 1), 454-455.

Harmon, D. L. (1991). Volatile fatty acid and glucose utilisation by the portal-drained viscera in ruminants. In Proceedings of the 12th EAAP Symposium on Energy Metabolism in Farm Animals (EAAP Publication No. 58) [C. Wenk \& M. Boessinger, editors]. Zürich, Switzerland: ETH-Zentrum.

Harmon, D. L. (1992). Dietary influences on carbohydrases and small intestinal starch hydrolysis capacity in ruminants. Journal of Nutrition 122, 203-210.

Harmon, D. L., Avery, T. B., Huntington, G. B. \& Reynolds, P. J. (1988). Influence of ionophore addition to roughage and high-concentrate diets on portal blood flow and net nutrient flux in cattle. Canadian Journal of Animal Science 68, 419-429.

Harmon, D. L., Gross, K. L.. Krehbiel, C. R., Kreikemeier, K. K., Bauer, M. L. \& Britton, R. A. (1991a). Influence of dietary forage and energy intake on metabolism and acyl-CoA synthetase activity in bovine ruminal epithelial tissue. Journal of Animal Science 69, 4117-4127.

Harmon, D. L., Gross, K. L., Krehbiel, C. R., Kreikemejer, K. K., Coffey, K. P., Avery, T. B. \& Klindt, J. $(1991 b)$. Effects of feeding endophyte-infected fescue hay on portal and hepatic nutrient flux in steers. Journal of Animal Science 69, 1223-1231.

Harmon, D. L., Kreikemeier, K. K. \& Gross, K. L. (1993). Influence of addition of monensin to an alfalfa hay diet on net portal and hepatic nutrient flux in steers. Journal of Animal Science 71, 218-225.

Harris, P. M., Skene, P. A., Buchan, V., Milne, E., Calder, A. G., Anderson, S. E., Connell, A. \& Lobley, G. E. (1992). Effect of food intake on hind-limb and whole-body protein metabolism in young growing sheep: chronic studies based on arterio-venous techniques. British Journal of Nutrition 68, 389- 407.

Häussinger, D. (1983). Hepatocyte heterogeneity in glutamine and ammonia metabolism and the role of an intercellular glutamine cycle during ureogenesis in perfused rat liver. European Journal of Biochemistry 133, $269-275$.

Heath, T. J. \& Perkins. N. R. (1985). Effect of development of the ovine forestomachs on the anatomy of portal vessels and on the intrahepatic distribution of portal blood. Research in Veterinary Science 39, 216-221.

Hediger, M. A., Coady, M. J., Ikeda, T. S. \& Wright, E. M. (1987a). Expression cloning and cDNA sequencing of the $\mathrm{Na}^{-}$/glucose co-transporter. Nature 330, 379-381.

Hediger, M. A., lkeda, T., Coady, M., Gundersen, C. B. \& Wright, E. M. (1987b). Expression of size-selected mRNA encoding the intestinal Na/glucose cotransporter in Xenopus laevis oocytes. Proceedings of the National Academy of Sciences, USA 84, 2634-2637.

Heitmann, R. N. \& Bergman, E. N. (1981). Glutamate interconversions and glucogenicity in the sheep. American Journal of Physiology 241, E465-E472.

Heitmann, R. N., Sensenig, S. C., Reynolds, C. K., Fernandez, J. M. \& Dawes, D. J. (1986). Changes in energy metabolite and regulatory hormone concentrations and net fluxes across splanchnic and peripheral tissues in fed and progressively fasted ewes. Journal of Nutrition 116, 2516-2524.

Hidalgo, I. J., Raub, T. J. \& Borchardt, R. T. (1989). Characterization of the human colon carcinoma cell line Caco-2 as a model system for intestinal epithelial permeability. Gastroenterology 96, 736-749.

Huntington, G. B. (1982). Portal blood flow and net absorption of ammonia-nitrogen, urea-nitrogen and glucose in nonlactating Holstein cows. Journal of Dairy Science 65, 1155-1162.

Huntington, G. B. (1983). Net nutrient absorption in beef steers fed silage or high concentrate diets containing four levels of limestone. Journal of Nutrition 113, 1157-1164.

Huntington, G. B. (1986). Uptake and transport of nonprotein nitrogen by the ruminant gut. Federation Proceedings 45, $2272-2276$.

Huntington, G. B. (1989). Hepatic urea synthesis and site and rate of urea removal from blood of beef steers fed alfalfa hay or a high concentrate diet. Canadian Journal of Animal Science 69, 215-223.

Huntington, G. B. \& Eisemann, J. H. (1988). Regulation of nutrient supply by gut and liver tissues. Journal of Animal Science 66 (Suppl. 3), 35-48.

Huntington, G. B., Eisemann, J. H. \& Whitt, J. M. (1990). Portal blood flow in beef steers: comparison of techniques and relation to hepatic blood flow, cardiac output and oxygen uptake. Journal of Animal Science 68, 1666-1673.

Huntington, G. B. \& Prior. R. L. (1983). Digestion and absorption of nutrients by beef heifers fed a high concentrate diet. Journal of Nutrition 113. 2280-2288.

Huntington, G. B., Prior, R. L. \& Britton, R. A. (1980). Glucose and lactate absorption and metabolic interrelationships in lambs switched from low to high concentrate diets. Journal of Nutrition 110, $1904-1913$. 
Huntington, G. B. \& Reynolds, P. J. (1983). Net volatile fatty acid absorption in nonlactating Holstein cows. Journal of Dairy Science 66, 86-92.

Huntington, G. B. \& Reynolds P. J. (1986). Net absorption of glucose, L-lactate, volatile fatty acids, and nitrogenous compounds by bovine given abomasal infusions of starch or glucose. Journal of Dairy Science 69. $2428-2436$

Huntington, G. B., Reynolds, C. K. \& Stroud, B. H. (1989). Techniques for measuring blood flow in the splanchnic tissues of cattle. Journal of Dairy Science 72, 1583-1595.

Huntington, G. B., Reynolds, P. J. \& Tyrrell, H. F. (1983). Net absorption and ruminal concentrations of metabolites in nonpregnant dry Holstein cows before and after intraruminal acetic acid infusion. Journal of Dairy Science 66, 1901-1908.

Huntington, G. B. \& Tyrrell, H. F. (1985). Oxygen consumption by portal-drained viscera of cattle: comparison of analytical methods and relationship to whole-body oxygen consumption. Journal of Dairy Science 68, $2727-2731$.

Huntington, G. B., Varga, G. A., Glenn, B. P. \& Waldo, D. R. (1988). Net absorption and oxygen consumption by Holstein steers fed alfalfa or orchardgrass silage at two equalized intakes. Journal of Animal Science 66. $1292-1302$

Johnson, D. E., Johnson, K. A. \& Baldwin, R. L. (1990). Changes in liver and gastrointestinal tract energy demands in response to physiological workload in ruminants. Journal of Nutrition 120,649-655.

Kaback, H. R. (1960). Uptake of amino acids by 'ghosts' of mutant strains of E coli. Federation Proceedings 19. 130.

Katz, M. L. \& Bergman, E. N. (1969a). A method for simultaneous cannulation of the major splanchnic blood vessels of the sheep. American Journal of Veterinary Research 30, 655 661.

Katz, M. L. \& Bergman, E. N. (1969b). Simultaneous measurements of hepatic and portal venous blood flow in the sheep and dog. American Journal of Physiology 216, 946-952.

Katz, N. R. (1992). Metabolic heterogeneity of hepatocytes across the liver acinus. Journal of Nutrition 122, 843-849.

Kelly, J. M., Vaage, A. S., McBride, B. W. \& Milligan, L. P. (1989). Oxygen consumption and the energy costs of $\mathrm{Na}^{+}, \mathrm{K}^{+}$-ATPase in rumen epithelial papillae from Hereford steers. Journal of Dairy Science 72 (Suppl. 1), 560 .

Koeln, L. L. \& Webb, K. E. (1982). Peptide, erythrocyte and plasma amino acid transport across gastrointestinal tract and liver of calves. Federation Proceedings 41, 948.

Krebs, H. A. \& Henseleit, K. (1932). [Formation of urea in the animal body.] Hoppe-Seyler's Zeitschrift für Physiologische Chemie 210, 33.66.

Krehbiel, C. R., Harmon, D. L. \& Schneider, J. E. (1992). Effects of increasing ruminal butyrate on portal and hepatic nutrient flux in steers. Journal of Animal Science 70, 904-914.

Kreikemeier, K. K., Harmon, D. L., Brandt, R. T. J., Avery, T. B. \& Johnson, D. E. (1991). Small intestinal starch digestion in steers: effects of various levels of abomasal glucose, corn starch and corn dextrin infusion on small intestinal disappearance and net glucose absorption. Journal of Animal Science 69, 328-338.

Lobley, G. E., Milne, V., Lovie, J. M., Reeds, P. J. \& Pennie, K. (1980). Whole-body and tissue protein synthesis in cattle. British Journal of Nutrition 43, 491-502.

Lomax, M. A. \& Baird, G. D. (1983). Blood flow and nutrient exchange across the liver and gut of the dairy cow. Effects of lactation and fasting. British Journal of Nutrition 49, 48l-496.

MacRae, J. C., Lobley, G. E., Bruce, L. A., Luo, Q., Calder, A. G. \& Farningham, D. A. H. (1993). Leucine kinetics across the portal drained viscera of sheep. Journal of Animal Science 71 (Suppl. 1), 279.

Maltby, S. A. (1993). Nutritional Regulation of Splanchnic Nitrogen and Energy Metabolism. PhD Thesis, University of Reading.

Maltby, S. A., Lomax, M. A., Beever, D. E. \& Pippard, C. J. (1991). The effect of increased ammonia and amino acid supply on postprandial portal-drained viscera and hepatic metabolism in growing steers fed maize silage. In Proceedings of the 12th Symposium on Energy Metabolism of Farm Animals (EAAP Publication No. 58), pp. 20- 23 [C. Wenk \& M. Boessinger, editors]. Zürich, Switzerland: ETH-Zentrum.

Mayes, R. W. \& Ørskov, E. R. (1974). The utilization of gelled maize starch in the small intestine of sheep. British Journal of Nutrition 32, 143-153.

McBride, B. W., Early, R. J. \& Ball, R. O. (1989). Protein synthesis and energy costs of $\mathrm{Na}^{+}, \mathrm{K}^{+}-$transport in tissues of somatotropin treated steers. In Energy Metabolism of Farm Animals (EAAP Publication No. 43), pp. 107-111 [Y. Van der Honing \& W. H. Close, editors]. Wageningen, Netherlands: Centre for Agricultural Publishing and Documentation (Pudoc).

McBride, B. W. \& Kelly, J. M. (1990). Energy cost of absorption and metabolism in the ruminant gastrointestinal tract and liver: a review. Journal of Animal Science 68, 2997- 3010.

McBride, B. W. \& Milligan, L. P. (1984). The effect of lactation on ouabain-sensitive respiration of the duodenal mucosa of cows. Canadian Journal of Animal Science 64, 817-824.

McBride, B. W. \& Milligan, L. P. (1985). Influence of feed intake and starvation on the magnitude of $\mathrm{Na}^{+}, \mathrm{K}^{+}-$ ATPase-dependent respiration in duodenal mucosa of sheep. British Journal of Nutrition 53, 605-614.

McCormick, M. E. \& Webb, K. E. (1982). Plasma free, erythrocyte free, and plasma peptide amino acid exchange of calves in steady state and fasting metabolism. Journal of Nutrition 112, 276-282. 
McGuire, M. A., Beede, D. K., DeLorenzo, M. A., Wilcox, C. J., Huntington, G. B., Reynolds, C. K. \& Collier, R. J. (1989). Effects of thermal stress and level of feed intake on portal plasma flow and net fluxes of metabolites in lactating Holstein cows. Journal of Animal Science 67, 1050-1060.

McLean, J. A. (1972). On the calculation of heat production from open-circuit calorimetric measurements. British Journal of Nutrition 27, 597-600.

Munck, B. G. (1972). Methodological problems in the study of amino acid transport by the small intestine. In Transport Across the Intestine, pp. 169-194 [W. L. Burland \& P. D. Samuel, editors]. London, England: Churchill Livingstone.

Newsholme, E. A. \& Leach, A. R. (1983). Amino acid metabolism. In Biochemistry for Medical Sciences, pp. 382-440 [E. A. Newsholme \& A. R. Leach, editors]. New York: John Wiley \& Son.

Nocek, J. E. \& Tamminga, S. (1991). Site of digestion of starch in the gastrointestinal tract of dairy cows and its effect on milk yield and composition. Journal of Dairy Science 74, 3598-3629.

Owens, F. N. \& Hanson, C. F. (1992). External and internal markers for appraising site and extent of digestion in ruminants. Journal of Dairy Science 75, 2605-2617.

Owens, F. N., Zinn, R. A. \& Kim, Y. K. (1986). Limits to starch digestion in the ruminant small intestine. Journal of Animal Science 63, 16341648

Parker, D.S. (1990). Manipulation of the functional activity of the gut by dietary and other means (antibiotics/probiotics) in ruminants. Journal of Nutrition 120, 639-648

Pearson, W. N., Schwink, T. \& Reich, M. (1966). In vitro studies of zinc absorption in the rat. In Zinc Metabolism, pp. 239-249 [A. S. Prasad. editor]. Springfield, IL: C. C. Thomas.

Pennington, R. J. (1952). The metabolism of short-chain fatty acids in the sheep. 1. Fatty acid utilization and ketone body production by the rumen epithelium and other tissues. Biochemical Journal 51, 251-258.

Peters, J. P., Shen, R. Y. W., Robinson, J. A. \& Chester, S. T. (1990). Disappearance and passage of propionic acid from the rumen of the beef steer. Journal of Animal Science 68, 3337-3349.

Phillips, W. A., Webb, K. E. \& Fontenot, J. P. (1976). In vitro absorption of amino acids by the small intestine of sheep. Journal of Animal Science 42, 201-207.

Piccioli Cappelli, F., Seal, C. J. \& Parker, D. S. (1993a). Portal glucose absorption and utilization in sheep receiving exogenous glucose intravascularly or intraduodenally. Journal of Animal Science 71 (Suppl. 1), 279.

Piccioli Cappelli, F., Seal, C. J. \& Parker, D. S. (1993b). $\left[1-{ }^{13}\right.$ C $]$ Leucine uptake into the portal vein of sheep receiving exogenous glucose intravascularly or intraduodenally. Proceedings of the Nutrition Society 52, 192A.

Pogson, C. I., Carpenter, W. R., Cook, J. S., Fisher, M. J., Lomax, M. A., Salter, M. \& Stanley J. C. (1984). A critical approach to the use of isolated liver cells for the study of metabolic events. Proceedings of the Nutrition Society 43, 119-132.

Prewitt, L. R., Jacobson, D. R., Hemken, R. W. \& Hatton, R. H. (1975). Portal blood flow as measured by the Doppler shift technique in sheep fed chopped forages. Journal of Animal Science 41, 596-600.

Ratner, S. (1947). The enzymatic mechanism of arginine formation from citrulline. Journal of Biological Chemistry 170, 761-762.

Read, M. V. P. (1988). Amino Acid and Metabolite Responses in Portal and Peripheral Blood of Silage-fed Sheep. PhD Thesis, Newcastle upon Tyne.

Reeds, P. J., Burrin, D. G., Davis, T. A. \& Fiorotto, M. L. (1993). Postnatal growth of gut and muscle competitors or collaborators? Proceedings of the Nutrition Society 52, 57-67.

Reynolds, C. K. (1992). Metabolism of nitrogenous compounds by ruminant liver. Journal of Nutrition 122. 850-854.

Reynolds, C. K., Casper, D. P., Harmon, D. L. \& Milton, C. T. (1992a). Effect of CP and ME intake on visceral nutrient metabolism in beef steers. Journal of Animal Science 70 (Suppl. 1), 315.

Reynolds, C. K. \& Huntington, G. B. (1988a). Partition of portal-drained visceral net flux in beef steers. 1. Blood flow and net fiux of oxygen. glucose and nitrogenous compounds across stomach and post-stomach tissues British Journal of Nutrition 60, 539-551.

Reynolds, C. K. \& Huntington, G. B. (1989b). Partition of portal-drained visceral net flux in beef steers. 2. Net flux of volatile fatty acids, $D$ - $\beta$-hydroxybutyrate and 1 -lactate across stomach and post-stomach tissues. British Journal of Nurrition 60,553-562.

Reynolds, C. K., Huntington, G. B., Elsasser, T. H., Tyrrell, H. F. \& Reynolds, P. J. (1989). Net metabolism of hormones by portal-drained viscera and liver of lactating Holstein cows. Journal of Dairy Science 72 , 1459-1468.

Reynolds, C. K., Huntington, G. B., Tyrrell, H. F. \& Reynolds, P. J. (1986). Splanchnic tissue and whole animal oxygen consumption by lactating Holstein cows. Journal of Dairy Science 69 (Suppl. 1), 193.

Reynolds, C. K., Huntington, G. B., Tyrrell, H. F. \& Reynolds, P. J. (1988a). Net portal-drained visceral and hepatic metabolism of glucose. L-lactate, and nitrogenous compounds in lactating Holstein cows. Journal of Dairy Science 71, 1803-1812.

Reynolds, C. K., Huntington, G. B.. Tyrrell, H. F. \& Reynolds, P. J. (1988b). Net metabolism of volatile fatty acids, D- $\beta$-hydroxybutyrate, nonesterified fatty acids, and blood gases by portal-drained viscera and liver of lactating Holstein cows. Journal of Dairy Science 71, 2395-2405.

Reynolds, C. K., Lapierre, H., Tyrrell, H. F., Elsasser, T. H., Casper, D., Gaudreau, P. \& Brazeau, P. (1993a). Intake and growth hormone-releasing factor (GRF) affect visceral metabolism of VFA in growing beef steers. Journal of Animal Science 71 (Suppl. 1), 270. 
Reynolds, C. K., Lapierre, H., Tyrrell, H. F., Flsasser, T. H., Staples, R. C., Gaudreau, P. \& Brazeau. P. (1992 b). Effects of growth-hormone releasing factor and feed intake on energy metabolism in growing beef steers: net nutrient metabolism by the portal-drained viscera and liver. Journal of Animal Science 70, 752763.

Reynolds, C. K. \& Tyrrell, H. F. (1991). Effects of mesenteric vein L-alanine infusion on liver metabolism in beef heifers fed on diets differing in forage : concentrate ratio. British Journal of Nutrition 66, 437-450.

Reynolds, C. K., Tyrrell, H. F. \& Armentano, L. E. (1992c). Effects of mesenteric vein $n$-butyrate infusion on liver metabolism by beef steers. Journal of Animal Science 70, 2250-2261.

Reynolds, C. K., Tyrrell, H. F. \& Harmon, D. L. (1991a). Effects of diet forage-to-concentrate ratio and mesenteric vein L-alanine infusion on visceral metabolism of volatile fatty acids in beef heifers. Journal of Dairy' Science 74 (Suppl. 1), 257

Reynolds, C. K., Tyrrell, H. F. \& Reynolds, P. J. (1991b). Effects of diet forage-to-concentrate ratio and intake on energy metabolism in growing beef heifers: whole body energy and nitrogen balance and visceral heat production. Journal of Nutrition 121, 994-1003.

Reynolds, C. K., Tyrrell, H. F. \& Reynolds, P. J. (1991 c). Effects of diet forage-to-concentrate ratio and intake on energy metabolism in growing beef heifers: net nutrient metabolism by visceral tissues. Journal of Nutrition 121. $1004-1015$.

Reynolds, C. K., Tyrrell, H. F. \& Reynolds, P. J. (1993b). Effects of diet forage-to-concentrate ratio and intake on net visceral metabolism of VFA in growing beef heifers. Journal of Dairy Science 76 (Suppl. 1), 283.

Roe, W. E., Bergman, E. N. \& Kon. K. (1966). Absorption of ketone bodies and other metabolites via the portal blood of sheep. American Journal of Veterinarv Research 27, 729-736.

Rooney, L. W. \& Pfugfelder, R. L. (1986). Factors affecting starch digestibility with special emphasis on sorghum and corn. Journal of Animal Science 63, 1607-1623.

Sakata, T. \& Tamate, H. (1978). Rumen epithelial cell proliferation accelerated by rapid increase in intraruminal butyrate. Journal of Dairy Science 61, 11091113.

Schambye, P. (1955). Experimental estimation of the portal vein blood flow in sheep. 1. Examination of an infusion method and results from acute experiments. Nordisk Veterinaer Medicin 7, 961-975.

Seal, C. J. \& Heaton, F. W. (1983). Chemical factors affecting the intestinal absorption of zinc in vitro and in vivo. British Journal of Nutrition 50, 317-324.

Seal, C. J. \& Mathers, J. C. (1989). Intestinal zinc transfer by everted gut sacs from rats given diets containing different amounts and types of dietary fibre. British Journal if Nutrition 62, 151-163.

Seal, C. J. \& Parker, D. S. (1991 a). Increased plasma free amino acid concentrations and net absorption of amino acids into portal and mesenteric veins with intra-ruminal propionate infusion into forage-fed steers. In Proceedings of the EAAP 6th International Symposium on Protein Metabolism and Nutrition, Herning, Denmark, pp. 184. 186 [B. O. Eggum, S. Boisen, C. Borsting, D. A. \& T. Hvelplund, cditors]. Foulum: National Institute of Animal Science.

Seal, C. J. \& Parker, D. S. (1991 b). Isolation and characterization of circulating low molecular weight peptides in steer, sheep and rat portal and peripheral blood. Comparative Biochemistry and Physiology $99 \mathrm{~B}, 679685$.

Seal, C. J. \& Parker, D. S. (1992). Glucose utilization by portal drained viscera of steers receiving intraruminal propionate infusion. Journal of Animal Science 70 (Suppl. 1), 294.

Seal, C. J. \& Parker, D. S. (1993a). Net mesenteric and portal absorption and rumen metabolism of volatile fatty acids in forage-fed steers receiving intraruminal propionic acid. Animal Production 56, $431 \mathrm{~A}$.

Seal, C. J. \& Parker, D. S. (1993 b). Net absorption of low molecular weight peptides by the mesenteric and portal drained viscera of steers. Proceedings of the Nutrition Society 52, 190 A.

Seal, C. J., Parker, D. S. \& Avery, P. J. (1992). The effect of forage and forage-concentrate diets on rumen fermentation and metabolism of nutrients by the mesenteric- and portal-drained viscera in growing steers. British Journal of Nutrition 67, 335370

Seal, C. J., Parker, D. S., Balcells, J. \& Mole, J. L. (1993a). Nitrogen digestion in forage-fed sheep with and without intraruminal propionate infusion. Journal of Agricultural Science 120, 107-114.

Seal, C. J., Parker, D. S. \& Lobley, G. E. (1993b). Effect of intraduodenal starch infusion on glucose metabolism of growing stecrs fed alfalfa. Journal of Animal Science 71 (Suppl. 1), 279

Sharp, W. M., Johnson, R. R. \& Owens. F. N. (1982). Ruminal VFA production with steers fed whole or ground corn grain. Journal of Animal Science 55, 1505-1514.

Shirazi-Beechey, S. P., Hirayama, B. A., Wang, Y., Scott, D., Smith, M. W. \& Wright, E. M. (1991 a). Ontogenic development of lamb intestinal sodium glucose co-transporter is regulated by diet. Journal of Physiology 437. 699708

Shirazi-Beechey, S. P., Smith, M. W., Wang, Y.\& James, P. S. (1991 b). Postnatal development of lamb intestinal digestive enzymes is not regulated by diet. Journal of Physiology 437, 691698.

Shoemaker, W. C. (1964). Methods and techniques for measurement of hepatic physiology and metabolism. In The Liver: Morphology, Biochemistry, Physiology, Volume 2, pp. 243266 [C. Rouiller, editor]. New York: Academic Press.

Shoemaker, W. C., Walker, T. B., Van Itallie, T. B. \& Moore, F. D. (1959). A method for simultaneous catheterization of major hepatic vessels in a chronic canine preparation. American Journal of Physiology 196, 311-314.

Sniffen, C. J. \& Jacobson. D. R. (1975). Net amino acid absorption in steers fed alfalfa hay cut at two stages of maturity. Journal of Dairy Science 58, 371-385. 
Stangassinger, M. \& Giesecke, D. (1986). Splanchnic metabolism of glucose and related energy substrates. In Proceedings of the 6th International Symposium on Ruminant Physiology, pp. 347-366 [L. P. Milligan, W. L. Grovum \& A. Dobson, editors]. Englewood Cliffs, NJ: Prentice Hall.

Stevens, C. E. \& Stettler, B. K. (1966). Factors affecting the transport of volatile fatty acids across rumen epithelium. American Journal of Physiology 210, 365-372.

Symonds, H. W. \& Baird, G. D. (1973). Cannulation of a hepatic vein, the portal vein and a mesenteric vein in the cow and its use in the measurement of blood flow rates. Research in Veterinary Sciences 14, 267-269.

Tagari, H. \& Bergman, E. N. (1978). Intestinal disappearance and portal blood appearance of amino acids in sheep. Journal of Nutrition 108, 790-803.

Tyrrell, H. F., Moe, P. W. \& Flatt, W. P. (1970). Influence of excess protein intake on energy metabolism of the dairy cow. In Proceedings of the 5th Symposium on Energy Metabolism of Farm Animals (EAAP Publication No. 13), pp. 69-72 [editors]. Zürich, Switzerland: Juris Druck-Verlag.

Van der Walt, J. G., Baird, G. D. \& Bergman, E. N. (1983). Tissue glucose and lactate metabolism and interconversions in pregnant and lactating sheep. British Journal of Nutrition 50, 267-280.

Vernay, M. (1989). Incidence of the circadian rhythm of the excretion pattern on acetate absorption and metabolism in the rabbit hind-gut. Reproduction, Nutrition, Développement 29, 185196.

Waldo, D. R. (1973). Extent and partition of cereal grain starch digestion in ruminants. Journal of Animal Science 37, $1062-1074$.

Wangsness, P. J. \& McGilliard, A. D. (1972). Measurement of portal blood flow in calves by dye dilution. Journal of Dairy Science 55, 1439-1446.

Webb, K. E. \& Bergman, E. N. (1991). Amino acid and peptide absorption and transport across the intestine. In Proceedings of the 7th International Symposium on Ruminant Physiology, Sendai, Japan, pp. 111-128 [T. Tsuda, Y. Sasaki \& R. Kawashima, editors]. London, UK: Academic Press.

Webb, K. E., Dirienzo, D. B. \& Matthews, J. C. (1993). Recent developments in gastrointestinal absorption and tissue utilization of peptides: a review. Journal of Dairy Science 76, 351-361.

Webb, K. E., Matthews, J. C. \& DiRienzo, D. B. (1992). Peptide absorption: a review of current concepts and future perspectives. Journal of Animal Science 70, 3248-3257.

Webster, A. J. F. (1980). Energy costs of digestion and metabolism in the gut. In Digestive Physiology and Metabolism in Ruminants, pp. 469-484 [Y. Ruckebusch \& P. Thivend, editors]. Lancaster, UK: MTP Press.

Webster, A. J. F., Osuji, P. O., White, F. \& Ingram, J. F. (1975). The influence of food intake on portal blood flow and heat production in the digestive tract of sheep. British Journal of Nutrition 34, 125-139.

Weekes, T. E. C. \& Webster, A. J. F. (1975). Metabolism of propionate in the tissues of the sheep gut. British Journal of Nutrition 33, 425-438.

White, S. W., Chalmers, J. P., Hilder, R. \& Korner, P. I. (1967). Local thermodilution method for measuring blood flow in the portal and renal veins of the unanaesthetized rabbit. Australian Journal of Experimental Biology and Medical Science 45, 453468.

Wilson, T. H. \& Wiseman, G. (1954). The use of sacs of everted small intestine for the study of the transference of substances from the mucosal to the serosal surface. Journal of Physiology 123, 116-125.

Wilton, J. C. (1989). The Effects of Ammonia upon the Metabolism of Carbohydrates and Amino Acids in the Liver of Growing Steers Offered Silage. PhD Thesis, University of Reading.

Windmueller, H. G. \& Spaeth, A. E. (1978). Identification of ketone bodies and glutamine as the major respiratory fuels in vivo for postabsorptive rat small intestine. Journal of Biological Chemistry 253, 69-76.

Windmueller, H. G. \& Spaeth, A. E. (1980). Respiratory fuels and nitrogen metabolism in vivo in small intestine of fed rats. Quantitative importance of glutamine, glutamate and aspartate. Journal of Biological Chemistry 255, 107-112.

Wolf, J. E. \& Bergman, E. N. (1972). Gluconeogenesis from plasma amino acids in fed sheep. American Journal of Physiology 223, 455-460.

Wolf, J. E., Bergman, E. N. \& Williams, H. H. (1972). Net metabolism of plasma amino acids by liver and portaldrained viscera of fed sheep. American Journal of Physiology 223, 438-446.

Zierler, K. L. (1961). Theory and use of arteriovenous concentration differences for measuring metabolism in steady and non-steady states. Journal of Clinical Investigation 40, 2111-2125. 